\title{
Medicinal plants and animals of an important seasonal dry forest in Brazil
}

\begin{abstract}
Ulysses Paulino Albuquerque ${ }^{1 *}$, Alanne Lucena de Brito ${ }^{2}$, André Luiz Borba do Nascimento ${ }^{1}$, Antonio Fernando Morais de Oliveira ${ }^{1}$, Carla Mirele Tabósa Quixabeira ${ }^{2}$, Diógenes de Queiroz Dias ${ }^{3}$, Eduardo Carvalho Lira², Flávia Santos Silva ${ }^{1}$, Gyllyandeson de Araújo Delmondes ${ }^{3}$, Henrique Douglas Melo Coutinho ${ }^{3}$, Mariana Oliveira Barbosa ${ }^{1}$, Melissa Fontes Landell ${ }^{4}$, Rômulo Romeu da Nóbrega Alves ${ }^{5}$, Washington Soares Ferreira Júnior ${ }^{6}$
\end{abstract}

\begin{abstract}
Research performed in recent years indicates that efforts are still needed to understand the advances in the Caatinga, an important dry seasonal forest, and identify its potential for bioprospecting. These efforts are also important for pinpointing the challenges that should be addressed in future research focused on identifying new candidates for pharmacological studies in this complex region. Thus, in this review, we present the main advances of studies on plants and medicinal animals in the Caatinga region and their implications for ethnopharmacology, and we then discuss future challenges to promote the search for candidates with pharmacological potential. Based on an exploration of the available literature, we performed a critical reading of the available evidence to provide a good scenario on the studies in the region. We find that despite the large number of studies available, it is necessary to organize efforts to fill gaps in different areas of knowledge and optimize the search for new natural products.
\end{abstract}

Keywords: Ethnobotany; Ethnopharmacology; Ethnozoology; Phytotherapy; Zootherapy

\footnotetext{
1 Departamento de Botânica, Universidade Federal de Pernambuco, Cidade Universitária, Av. prof. Moraes Rego s/n, 50670901, Recife, PE, Brazil.

2 Departamento de Fisiologia e Farmacologia, Universidade Federal de Pernambuco, Cidade Universitária, Av. prof. Moraes Rego s/n, 50670-901, Recife, PE, Brazil.

${ }^{3}$ Departamento de Química Biológica-DQB, Universidade Regional do Cariri - URCA, Crato, CE, Brazil.

${ }^{4}$ Setor de Genética, Laboratório de Diversidade Molecular, Universidade Federal de Alagoas, Campus A. C. Simões, CEP: 57072-900, Maceió, AL, Brazil.

${ }^{5}$ Departamento de Biologia, Universidade Estadual da Paraíba, Av. das Baraúnas, 351/Campus Universitário, Bodocongó, 58109-753, Campina Grande-PB, Brazil.

${ }^{6}$ Laboratório de Investigações Bioculturais no Semiárido, Universidade de Pernambuco, Campus Petrolina, BR203, Km 2, s/n, CEP: 56328-903, Petrolina, PE, Brazil.
}

* Corresponding author. $₫ \mathrm{E}$-mail address: upa677@hotmail.com 


\section{INTRODUCTION}

Brazil possesses a rich diversity of fauna used for medicinal purposes (Alves et al. 2007, 2008a). Studies indicate that the northeast region possesses the largest volume of information on the use of medicinal fauna products (Alves and Rosa 2006 2007a, 2007b, 2007c; Alves 2009). The contribution of this information has stimulated the development of studies seeking to validate the medicinal activities of zootherapies described in ethnozoological studies in this region (Ferreira et al. 2010, Cabral et al. 2013; Oliveira et al. 2014; Sales et al. 2015).

The Caatinga of northeastern Brazil has an extensive area of $912,529 \mathrm{~km}^{2}$ and represents an important ecological region since it shelters considerable biodiversity and is a semi-arid region that covers several human groups with different sociocultural characteristics (Silva et al. 2017a). In relation to biodiversity, recent studies have registered 4,662 species of native plants (31 endemic genera) (Queiroz et al. 2017), 371 native species of fish (203 are possibly endemic) (Lima et al. 2017), 98 species of amphibians (20 endemic) (Garda et al. 2017), 79 species of lizards (38 endemic) (Mesquita et al. 2017), 548 species of birds (67 native) (Araújo and Silva 2017) and 138 species of mammals (11 endemic species) (Carmignotto and Astúa 2017). This large diversity involves species that have adaptations to deal with low water availability environments, which is important because precipitation is concentrated in a few months and rains are irregular in the region (Silva et al. 2017b).

In addition to the diversity of environments and species, several human groups inhabit the region, such as "Maroon," indigenous and rural communities, which interact with the Caatinga biota (Albuquerque et al. 2017). In the last decades, many studies have investigated the interactions of people with plants and animals in Caatinga areas (Albuquerque et al. 2007, 2017; Melo 2017). These resources are applied to a wide variety of uses, such as medicinal, construction, food, religious, technological, fuel, etc., thus indicating the high diversity of useful species (see Albuquerque et al. 2007, for medicinal plants).

When considering the biological and cultural diversity of the Caatinga of northeastern Brazil as well as the variety of species indicated as medicinal, this region has an important potential for ethnopharmacological studies focused on understanding the patterns of knowledge and use of medicinal resources by human populations and identifying candidates with important pharmacological activities. To evaluate the effects of bioprospecting, several research studies have been carried out in the Caatinga environment, and their findings indicate that the plants and animals in the region have pharmacological potential for a variety of diseases (Leal et al. 2009; Cabral et al. 2013; Campos et al. 2014).

Some work has gone deeper in the pursuit of patterns to identify the motives associated with the choice of medicinal resources to compose local pharmacopoeias in the Caatinga (Alencar et al. 2010; Lucena et al. 2012; Alencar et al. 2014). These works may be promising for ethnopharmacology as they investigate the formation of local medical systems. These systems involve the set of social institutions and traditions generated from the evolution of strategies that promote the health and well-being of a given locality (Dunn 1976). To understand issues related to traditional medicines, ethnopharmacology has 
accessed the knowledge present in local medical systems. However, the use of local remedies is complex, and several factors can influence the use of resources for the treatment of diseases. For example, the local significance of diseases, local norms linked to the healing process, social relations and existing institutional contexts are factors that influence the choice and evaluation of treatment efficiency (Kleinman 1978).

In this article, we present an overview of the state of the art on the medicinal animals and plants in the Caatinga and highlight ethnopharmacological, phytochemical and pharmacological advances.

\section{Local medical system from the Caatinga and its relevance for ethnopharmacology}

The Caatinga presents a wealth of medicinal plants. Currently, the most important checklist on the medicinal plants of the Caatinga is that produced by Albuquerque et al. (2007), which reported a total of 385 species of angiosperms and four species of ferns and mosses used for medicinal purposes in 21 studies conducted in the region. We used the basis of this study (Albuquerque et al. 2017) to make some of our considerations here. Studies on medicinal plants in the Caatinga usually present a list of medicinal plants and their uses, as well as an index to highlight the most important plants (see Medeiros et al. 2011a). One of the main arguments for the use of these indices is to promote the selection of plants for future pharmacological investigations. However, fewer papers were devoted to describing and testing hypotheses about how these plants fit into the complex local medical systems of the Caatinga.

A considerable amount of evidence has been obtained from studies conducted in the Caatinga and other regions showing that the use of plants for medicinal purposes is the result of a long process of experimentation (see Medeiros et al. 2013; Ankli et al. 1999). Thus, people use certain criteria to recognize a plant as potentially effective, include it in the local pharmacopoeia, and determine the plant that will be used at the time that a disease episode occurs (see Figure 1). Organoleptic properties of plants, such as the color, shape, aroma, taste and texture, act as signs that lead to the inclusion of species in the local medicinal repertoire (Ankli et al. 1999; Casagrande 2000). An association can exist between people's perceptions of the taste and smell of plants and the diseases that they are used to treat, but not in all cases. In this sense, bitter taste may be a core organoleptic property used to treat the most popular diseases (see Medeiros et al. 2015). Only those diseases found most frequently in the lists were associated with a bitter taste, which indicates that bitter taste may be a core organoleptic property used to treat the most popular diseases.

The importance of the disease to be treated in the selection of the medical resource was highlighted in the study by Ferreira Júnior et al. (2016). This study indicates that diseases with similar symptoms have greater similarities to the set of medicinal plants used for their treatment. Considering this finding and that of Medeiros et al. (2015), people in the Caatinga choose resources with similar organoleptic characteristics for medicinal functions that are also perceived as similar. In this case, it is possible that plant characteristics are involved in the selection of medicinal resources when comparing different human groups located in different regions. The study by Saslis-Lagoudakis et al. (2012) 
showed that human groups located in different regions select phylogenetically related medicinal plants to treat the same classes of diseases. The authors point out that human groups may have selected these plants independently based on their therapeutic efficacies. In another example, the study of Geck et al. (2017), which was carried out in different communities in Chiapas, Mexico, observed that the smell and taste of the plants provided important information about the humoral ("hot" or "cold") properties, thus guiding their medicinal applications. This finding may have important implications for future strategies linked to bioprospecting because it can be used to evaluate what characteristics of plants guide the construction of medical systems and determine whether these characteristics are linked to important pharmacological activities of plants.

From the characteristics of plants that can guide their selection, it is possible that redundant plants (Albuquerque and Oliveira 2007) used to treat one or more diseases share a certain set of characteristics, such as organoleptics (e.g., bitter-tasting plants targeted for certain diseases, in Medeiros et al. 2015) or chemical properties. In the case of the Caatinga, medicinal plants used for the treatment of inflammation are associated with the presence of tannins (Araújo et al. 2008). Other studies have shown that these

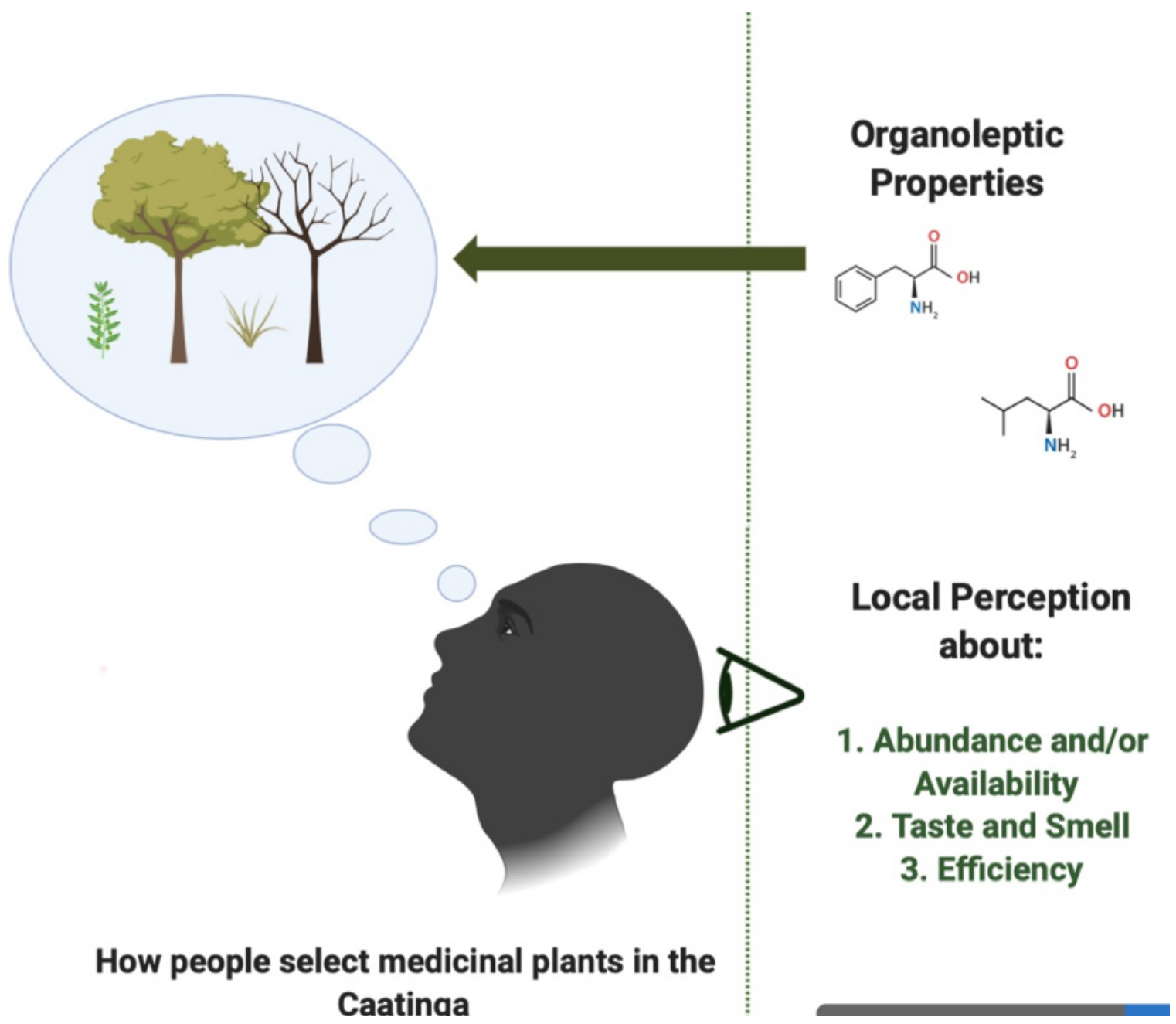

Figure 1. Some insights on how people select medicinal plants in the Caatinga. 
compounds can be perceived through the astringency taste (see, for example, Dragos and Gilca 2018).

The recurrence of a disease event appears to be an important factor for structuring local medical systems. Some studies have shown that diseases considered frequent tend to be associated with a large number of medicinal plants (Santoro et al. 2015; Nascimento et al. 2016). Sousa et al. (2016) found that the species cited first in lists of medicinal plants are those that have been used to treat diseases that have occurred in the last year, and these plants are also considered as more important, but new studies need to be conducted to confirm or not this finding.

All of these data suggest that most studies in the Caatinga have accessed and inferred patterns concerning diseases that are most common in the local medical system. Apparently, the most relevant medical information for people is how to deal with recent and/or recurring illness events, which is interesting because it is widespread within the discourse of many authors working with medicinal plants, who consider that the most popular plants are the most relevant for bioprospecting.

In addition to the application of plants for the treatment of frequent diseases, different therapeutic modalities can also be used for these diseases. The study by Nascimento et al. (2018) found that the combined use of plants with medicinal products of biomedical origin can be favored in diseases with high frequency of occurrence according to local perception. An interesting example is the case of the Fulni-ô Indians, whose strategies for health management include the use of plants, visits to practitioners (local specialists), and the use of biomedical drugs (see also Soldati and Albuquerque 2012; Zamudio and Hilgert 2011). However, such combined use can have negative consequences for people from a pharmacological point of view. Several studies have observed adverse effects when medicinal plants are given in conjunction with conventional drugs (Staines 2011; Larson et al. 2014; Murray et al. 2016). For example, plant extracts of different species may affect the expression of the CYP2D6 gene, which produces an important drugmetabolizing enzyme that may cause toxic reactions with or inhibit therapeutic effects when the extracts are administered along with conventional drugs (Feltrin et al. 2019). Therefore, future studies should focus on the interactions between medicinal plants native to the Caatinga and conventional drugs.

In addition to plant-drug interactions, the accumulation of distinct treatments (plants and drugs of biomedical origin) in diseases with a higher frequency of occurrence can increase the probability of maladapted information in local medical systems, i.e., the inclusion of plants that are not effective in the treatment of these diseases (Tanaka et al. 2009; Santoro et al. 2018). For example, according to the model proposed by Tanaka et al. (2009), diseases with higher frequencies of occurrence can increase the chance of non-effective plants being copied among pairs of people in a human group. Santoro et al. (2015) also explained that a greater number of species used for frequent diseases can be related to information transmission errors.

Therefore, future investigations could assess how much non-effective plants are present in local medical systems and the factors that increase the probability of insertion of these plants over time. If these transmission errors are frequent in local medical systems in the Caatinga, then caution should be exercised in the selection of medicinal plants in future studies on 
bioprospecting because some of these plants cited for different uses may not be effective in the treatment of certain diseases. Moreover, future research should exercise caution when selecting plants for pharmacological evaluation by including plants prescribed for diseases that are highly frequent in a given region as a criterion.

Another important factor is that not all species known for medicinal purposes or even for a given disease are actually used by a community (Albuquerque 2006), and one plant is often used more frequently than others. Several factors may be involved in the differential use of medicinal plants (see Medeiros et al. 2015); therefore, different criteria have been associated with the prioritization of a medicinal plant in human groups in the Caatinga. For example, Ferreira Júnior et al. (2011) found that the most cited criterion for prioritizing a plant was its perceived therapeutic efficacy. In this case, a plant that is widely cited as preferred because of its perceived efficacy for a large set of diseases may be of interest for future pharmacological investigations aimed at bioprospecting (Ferreira Júnior et al. 2011; Albuquerque et al. 2014).

However, in addition to the perceived efficiency, other criteria are important in the prioritization of medicinal plants. In addition, factors such as accessibility to the resource can promote greater experimentation and learning (Molares and Ladio 2008), thus leading to greater use of these species. Cost-benefit relationships can guide the exploration of medicinal resources, in which a shorter time spent during collection demonstrates weight in the choices of human populations (Soldati and Albuquerque 2012). In environments with marked seasonality, such as the Caatinga, the temporal availability of the species may be another factor that leads to the differential use of medicinal plants; for example, the study of Albuquerque (2006) reports the greater use of the bark of arboreal species in this region because they are found in the environment during the whole year. These environmental factors need to be taken into account since people may come to use more of a medicinal feature not for its efficiency but for its ease of collection. Many medicinal plants are transported by people to the backyards of their homes, for example, to avoid the costs associated with their collection.

In addition to plant resources, products of animal origin are frequent in Caatinga folk medicine. There is an expressive richness of species of medicinal animals used by human populations that live in the region, and these species encompass several groups of invertebrates and vertebrates (Alves et al. 2016a,b; Alves et al. 2012; Bezerra et al. 2013; Mendonça et al. 2014). Ethnozoological reviews indicate that at least 24 reptile species (Alves et al. 2012) and 38 mammal species (Alves et al. 2016a,b) are used for medicinal purposes in the region. Other groups, such as birds, amphibians and fish, are also registered as a source of medicine in the region's folk medicine (Bezerra et al. 2013; Santos and Alves 2016). Among invertebrates, insects stand out (Alves 2009). Curiously, medicinal species of marine origin are used in the region, and they are obtained in public markets in urban areas and are usually obtained from clandestine commercialization (Alves et al. 2009b). Zootherapy is also a practice employed in ethnoveterinary medicine in the region (Souto et al. 2011), and at least 39 animal species have been reported as source of remedies used in local ethnoveterinary medicine for the production of medicines used to treat diseases of domestic animals. 
Animals are used in whole or in part, such as the feather, leg, hair, leather, tooth, lard (fat), flesh, spur, horn, scales, nail, blood, penis, bones, liver, heart, head, testicle, marrow, eye, ear, etc. Products of their metabolism, such as excreta (feces, urine) and honey, as well as materials built by animals, such as nests and cocoons, are also medicinally usable resources. Milk, blood and eggs are also part of the therapeutic arsenal. In most cases, the products are extracted after the animal's death since such raw materials are primarily obtained mainly through fishing and hunting activities, a common practice in the region (Alves et al. 2009a; Fernandes-Ferreira and Alves 2017). It is emphasized that slaughter is not always directly related to the medicinal use of animals. For example, in the municipality of Pocinhos, Paraíba, tejuaçú (Tupinambis merianae) is hunted mainly for food purposes, and the by-products thereof, such as lard and tongue, are used in the elaboration of popular remedies. Another example is the rattlesnake (Crotalus durissus), which is an animal that poses a risk to humans and domestic "creations;" therefore, it is usually slaughtered only under precaution or control (Alves 2009), and its by-products are used in zoos. Thus, the use of medicinal products optimizes the use of slaughtered animal resources. Moura and Marques (2008) point out that a common feature in fractions of animals or even whole animals used as medicines is their uselessness for other purposes. These authors also point out that although studies on Brazilian popular zootherapy have not yet turned to the quantitative analysis of the use of leftovers or animal by-products, the practice is well documented in the lists of zootherapies used in different Brazilian states (Alves et al. 1990) as well as in the literature (Martínez 2013).
It is also worth noting that live animals are used in zootherapeutic practices. For example, jabutis (Chelonoidis sp.) are usually raised as pets because this practice is believed to prevent bronchitis and erysipelas among the residents of the breeder's home (Alves et al. 2012). Another example is recorded in the semi-arid states of Paraíba and Pernambuco, where the live song (Cyanocorax cyanopogon) is used in popular "sympathy" treatments for asthmatic processes in which the bird is fed with the patient's food remains (Alves et al. 2009b). Raw animal materials are also used in the form of amulets and in "sympathies" to prevent and treat diseases associated with unnatural causes (Alves and Rosa 2006). The interrelation between popular beliefs and zootherapy has been recorded in different localities of Brazil (Alves et al. 2007).

The application of remedies prepared from animal substances varies according to the nature of the disease, the purpose of use and the ingredients used. Thus, different modes of preparation and administration of zootherapeutic resources are reported (Alves 2009). Hard parts of animals, such as shells, are usually sun dried, then trodden or grated, resulting in a powder, which is then used for tea preparation or ingested along with food. Some biotherapeutic products can be used in association with medicinal plants in "garrafadas," a therapeutic drink that may have products derived from animals and plants that are usually soaked in cachaça (sugarcane brandy) or white wine and stored in bottles (hence the name 'bottled').

A significant portion of the fauna with medicinal value is marketed by sellers in markets and free fairs throughout the Caatinga region (Alves et al. 2008a,b; Alves et al. 2010; Alves et al. 2009b; Costa-Neto 1999). Trade in zootherapies involves a wide 
variety of species, including whole animals (when small), although the commercialization of parts (derived from animals of medium and large size) is more common.

It is important to emphasize that some natural products (derived from plants, animals and minerals) used in traditional medicine can cause serious adverse effects and transmit zoonoses (Van Vliet et al. 2017), especially when considering the sanitary conditions associated with the maintenance and storage of the products (Alves et al. 2009b). This study, there was a significant increase in the prevalence of this disease in the Brazilian semi-arid region, which indicates the possibility of microbiological contamination and represents a potential risk to the users' health (Alves et al. 2007). A good example of this is "armadillos," which are hunted and used for food and medicinal purposes (Alves et al. 2009a; Barboza et al. 2016).

2. Major compounds identified in Caatinga plants

Several studies point to the great variety of secondary metabolites found in Caatinga species (see, for example, Almeida et al. 2011). It is believed that the synthesis of the secondary metabolites in this type of vegetation is favored by the adverse environmental conditions typical of this ecosystem that can influence the biosynthesis routes of compounds associated with plant defenses against biotic and abiotic factors (Montanari and Bolzani 2001; Almeida et al. 2011). Some of the key metabolites identified to date are described below and summarized in Table 1 .

\subsection{Alkaloids}

Alkaloids are a group of heterogeneous nitrogenous secondary metabolites widely recognized for their therapeutic effects, especially on their action on the nervous system, as well as their analgesic, hallucinogenic and antitumor effects (Makkar et al. 2007). Several studies point to the presence of these metabolites in Caatinga plants (Almeida et al. 2005, NascimentoSilva et al. 2011, Brandão et al. 2017), particularly in Apocynaceae, Erythroxylaceae and Fabaceae (Nogueira et al. 2014; Negreiros Neto et al. 2016; Ceravolo et al. 2018; Macedo Pereira et al. 2018). Aspidosperma pyrifolium Mart., for example, may be among the most studied species of the Caatinga in relation to their alkaloidal profile (Gilbert et al. 1962; Craveiro et al. 1983; Araújo et al. 2007). In Erythroxylum pungens O.E.Schulz (Erythroxylaceae), were identified twelve alkaloids in which one 3-(2-methylbutyryloxy)tropan-6,7-diol,

showed $50 \%$ cell viability reduction against HeLa (Macedo Pereira et al. 2018). According to these author, edaphoclimatic features of Caatinga biome could stimulate the biosynthesis of the unusual alkaloids, e.g. tropane alkaloids.

\subsection{Phenolics and Flavonoids}

Flavonoids are secondary phenolic metabolites that are mainly found in highquality vegetables, and they are responsible for conferring color to flowers and fruits and protection against UV and pathogens. In human foods, flavonoids contribute to several health benefits mainly because of their antioxidant effect (Buckingham and Munasinghe 2015). They are also known for their pharmacological importance because of their anti-inflammatory, antioxidant, 
antifungal and antitumor properties, among others (Cordeiro et al. 2018).

Most studies on species occurring in the Caatinga have concentrated on quantifying the total flavonoid content. However, refined methods of identifying flavonoids have also been employed, such as direct flow injectionelectrospray-ion trap tandem mass spectrometry (DFI-ESI-IT-MS) or even highperformance liquid chromatography with a diode-array detector (HPLC-DAD). Some studies, for example, have led to the isolation of isoquercetin, quercetin and rutin in Caryocar coriaceum Wittm. - Caryocaceae (Alves et al. 2017), gallic acid, rutin, ellagic acid, catechin, quercetin, kaempferol and caffeic acid were identified in Terminalia argentea Mart. - Combretaceae (Beserra et al. 2018), gallic acid and hyperoside in Spondias tuberosa Arruda - Anacardiaceae (Cordeiro et al. 2018) and amentoflavone and agathisflavone in Poincianella pyramidalis (Tul.) LP Queiroz - Fabaceae (Pereira Gomes-Copeland et al. 2018). Recently, kaempferol, quercetin, isorhamnetin and myricetin were identified in Ziziphus joazeiro Mart. - Rhamnaceae (Andrade et al., 2019).

\subsection{Tannins}

Tannins are phenolic compounds known especially for their astringency and ability to chemically bind to proteins, sugars and alkaloids. They present an important ecological function and are used by plants as a defense strategy against herbivores (Monteiro et al. 2005). Economically, they are used in the manufacture of leather products. Tannin-rich species are used in folk medicine mainly for their antidiarrheal, antiseptic, antifungal, antimicrobial, antiinflammatory and healing effects (Mello and Santos 2001; Monteiro et al. 2005).
According to Almeida et al. (2011), tannins are one of the most investigated and most frequent compounds in the medicinal plants of the Caatinga. Species such as Anacardium occidentale L. (Anacardiaceae), Anadenanthera colubrina (Vell.) Brenan (Fabaceae), A. falcata (Benth.) Speg. (Fabaceae), Caesalpinia ferrea Mart. ex Tul. (Fabaceae), Casearia sylvestris var. angustifolia Uittien (Flacourtiaceae), Cnidoscolus urens (L.) Arthur and C. infestus Pax \& K. Hoffm. (Euphorbiaceae), Lafoensia replicata Pohl. (Lythraceae), Myracrodruon urundeuva Allemão (Anacardiaceae), and Terminalia brasiliensis (Cambess.) Eichler (Combretaceae) are referred to as having a high amount of tannins (Araújo et al. 2008; Peixoto Sobrinho et al. 2011; Monteiro et al. 2014). Despite the high number of species, most tannin studies were limited to quantifying their levels in sought to correlate their presence with their therapeutic effects and their use value by local communities (Araújo et al. 2008; Monteiro et al. 2005; Siqueira et al. 2012; Monteiro et al. 2014). An exception is the study of Beserra et al. (2018), which have identified terminalin, corilagin, punicalin and punicalagin in the leaves of the $T$. argentea.

\subsection{Volatile oils and diterpenes}

Volatile oils (mono-10C and sesquiterpenes-15C) consist of a mixture of aliphatic and cyclic compounds derived from isoprene (5C). Volatile or essential oils have different functional groups in their structure, such as hydrocarbons, alcohols, aldehydes, esters, ethers and ketones, and they are mainly responsible for the odor of plants, the main function of which is to attract and/or repel herbivorous insects.

Several aromatic species are observed in Caatinga flora, and the main studies on 
essential oils in this environment have focused on the chemical composition of the oils, seasonal effects on the chemical profile of the oil and the biological activity of the oil. Euphorbiaceae family, especially the genus Croton (Dourado et al. 2005; Neves and Camara 2012; Ramos et al. 2013; Almeida et al. 2014a; Carvalho et al. 2016; Souza et al. 2017; Anjos et al. 2018; Ribeiro et al. 2018), Annonaceae (Meira et al. 2015; Araújo et al. 2015a; Diniz et al. 2019), Verbenaceae (Neves et al. 2008; Souza et al. 2018) and Lamiaceae (Pereira et al. 2018) contains the largest number of studies.

Diterpenes are terpenoids with 20 carbon atoms originating biosynthetically from geranylgeranyl diphosphate (GGPP) and are classified as linear, bicyclic, tricyclic, tetracyclic, pentacyclic and macrocyclic. Diterpenes have attracted increasing attention because of their numerous biological and pharmacological activities (Lanzotti 2013). Compared with studies on volatile oils, work with diterpenes in Caatinga species is scarce and has concentrated on a few species such as Calliandra depauperata Benth. - Fabaceae (Pires et al. 2011), Croton grewioides Baill. - Euphorbiaceae (Medeiros et al. 2011b), Erythroxylum revolutum Mart. - Erythroxylaceae (Oliveira 2012), and Cnidoscolus quercifolius Pohl -Euphorbiaceae (Oliveira-Júnior et al. 2018).

\subsection{Triterpenes and allied compounds}

The triterpenes are terpenoids with 30 squalene-derived carbon atoms, generally with five ring systems. They differ from phytosteroids because they have less than 30 carbons and are usually tetracyclic. Some studies have interrogated triterpenes in Caatinga species (Silva et al. 2010; Barbosa et al. 2014; Araújo Gómez et al. 2014; Vieira et al. 2016). Acids triterpenes such as betulinic, oleanolic and ursolic acids, besides lupeol, $\alpha$-amyrin, $\beta$-amyrin, cycloeucalenol, friedelin and derivatives were identified from Caatinga species (Barbosa-Filho et al. 1985; Silva et al. 2010; Vieira et al. 2016; OliveiraJúnior et al. 2018). For phytosteroids, most of the studies have performed phytochemical screening (Peixoto et al. 2016; Pereira et al. 2017). To the best of our knowledge, phytosteroids were isolated and identified in only two studies: Senna spectabilis var. excelsa (Schrad.) H.S.Irwin \& Barneby Fabaceae (Silva et al. 2010) and Pilosocereus pachycladus F. Ritter Cactaceae (Brito-Filho et al. 2017).

Saponins are glycosides which provide sugars and aglycones (sapogenins) under hydrolysis, which may be triterpene or steroidal. Studies on saponins in Caatinga species are limited, with the majority of studies only indicating the presence and absence of these metabolites (Peixoto Sobrinho et al. 2012; Pereira et al. 2016; Pereira et al. 2017; Cordeiro et al. 2018). Studies on the structural properties of saponins in the Caatinga have primarily focused on Z. joazeiro, a tree with stem bark rich in saponins $(2-10 \%)$ that is used by local communities as detergent and phytotherapic (Higuchi et al. 1984; Ribeiro et al. 2013; Ribeiro et al. 2014) and Manilkara rufula (Miq.) H.J.Lam (Sapotaceae), which presents antitrichomonal activity (Vieira et al. 2017).

To the best of our knowledge, there are no studies focused on isolation, purification and structural elucidation of cardenolides in Caatinga species, although families such as Apocynaceae are very representative in this ecosystem. 


\subsection{Fatty acids and other lipids}

Several Caatinga species are rich sources of fatty acids and other lipids of economic interest. Fatty acids consist of straight chain carboxylic acids found primarily in seeds in the form of triglycerides, and they are often associated with antioxidant compounds such as carotenoids, tocopherols, and tocotrienols (Gunstone 1996; Barbosa et al. 2019). In the Caatinga, the Euphorbiaceae, Sapindaceae and Malvaceae families stands out because of the large number of potentially oleaginous species (Pinho et al. 2009; Barros et al. 2015; Coutinho et al. 2015; Coutinho et al. 2016; Silva et al. 2010; Silva et al. 2014).

Another group of lipids studied in Caatinga plant species are those that constitute cuticular waxes, which are formed of aliphatic and cyclic constituents and cover the primary aerial surface of plants. The primary function of these waxes is to reduce water loss, especially under water stress situations, which are common in the Caatinga. Several aliphatic compounds (nalkanes, fatty acids, primary and secondary alcohols and ketones) have been identified as well as triterpenes such as $\alpha$-amyrin, $\beta$ amyrin, betulin, lupeol, epifriedelinol, ursolic acid, oleanolic acid, and betulinic acid (Oliveira et al. 2000; Costa Filho et al. 2012; Medeiros et al. 2017; Pereira et al. 2019).

\section{Biological activity of medicinal plants from the Caatinga}

Many of the Caatinga's plant are widely used in Brazilian traditional medicine and as phytomedicine products, and they include Myracrodruon urundeuva All., Amburana cearensis (Arr. Cam.) A.C. Sm., Erythrina velutina Willd., Anadenanthera colubrina
(Vell.) Brenan (Magalhães et al. 2019). The number of medicinal plants indicates the importance of this environment, and experimental approaches focused on such species have improved. To rationally explore the possible uses of this biome, its potential needs to be demonstrated scientifically. Considering the Caatinga biome, improving our knowledge about medicinal flora can provide alternatives to treating common diseases and will also serve preserve the genetic, biological and cultural diversity. We will present below some of the main studies that have accumulated data on plants of great cultural importance in the region (see Albuquerque et al. 2007).

\subsection{Amburana cearensis (Allemão)} A.C. Smith

A. cearensis is a native tree commonly found in the Brazilian semi-arid region and the Caatinga biome, where it is popularly known as 'cumaru,' 'amburana-de-cheiro' or 'umburana' (Albuquerque et al. 2007; Leal et al. 2005, 2009). Its trunk bark and seeds are widely used in folk medicine for the treatment of respiratory disease, pain, worm infections, sore throat, and inflammation and as antitussive and antispasmodic agents (Bitu et al. 2015).

The anti-inflammatory and bronchodilator activities of $A$. cearensis were promoted by carrageenan and $\mathrm{N}$-formyl-methyl-leucylphenylalanine (fMLP)-induced migration in rat peritoneal cavities (Leal et al. 2003). The crude ethanolic extract of $A$. cearensis leaves was shown to have a positive effect on ovarian cell cultures, and the antioxidant compounds could protect ovarian follicles from Reactive Oxygen Species (ROS) during in vitro culture (Barberino et al. 2016; Gouveia et al. 2016). The A. cearensis extract increased the rate of antrum 
Table 1. Major compounds identified in Caatinga plants.

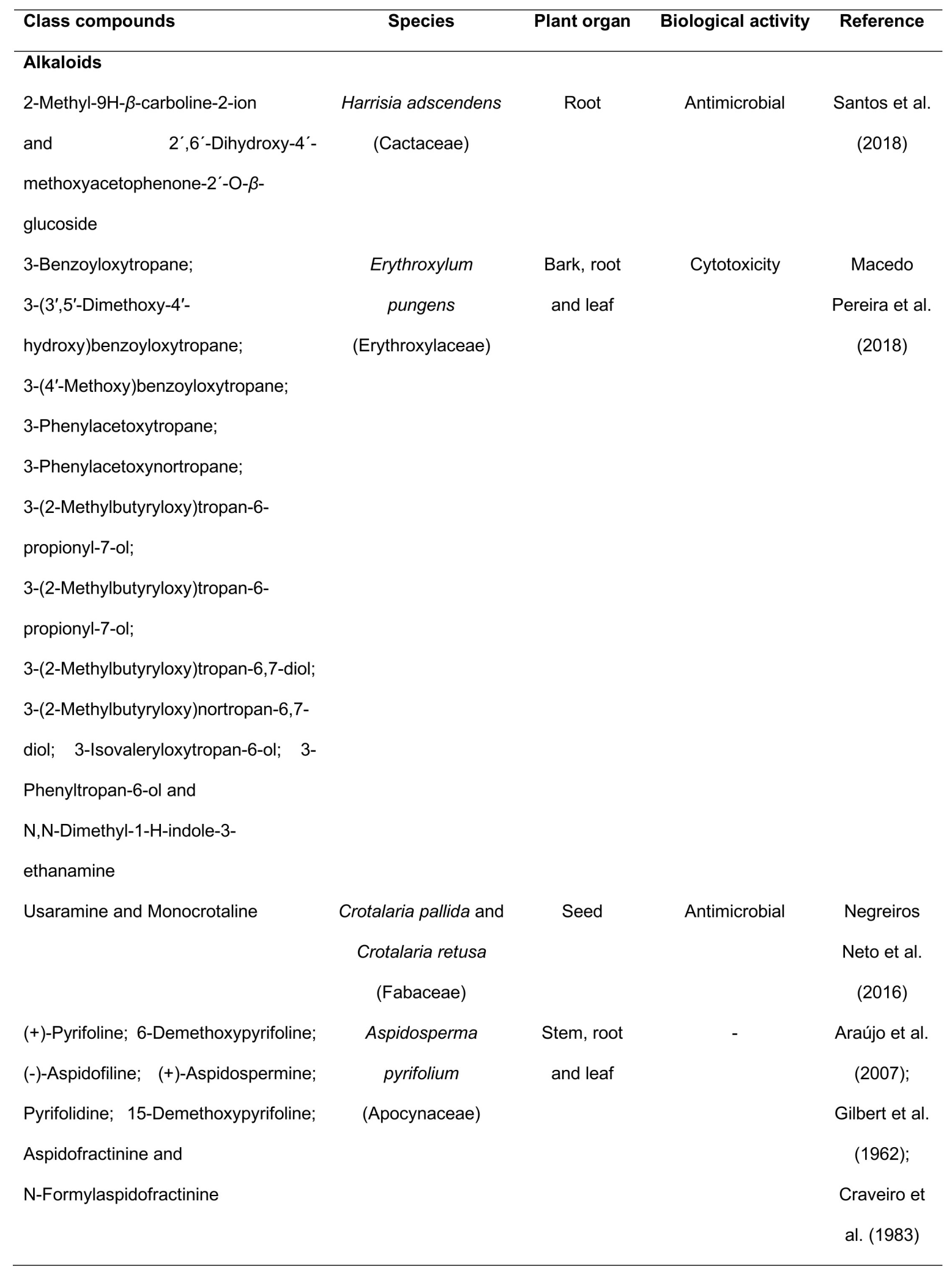




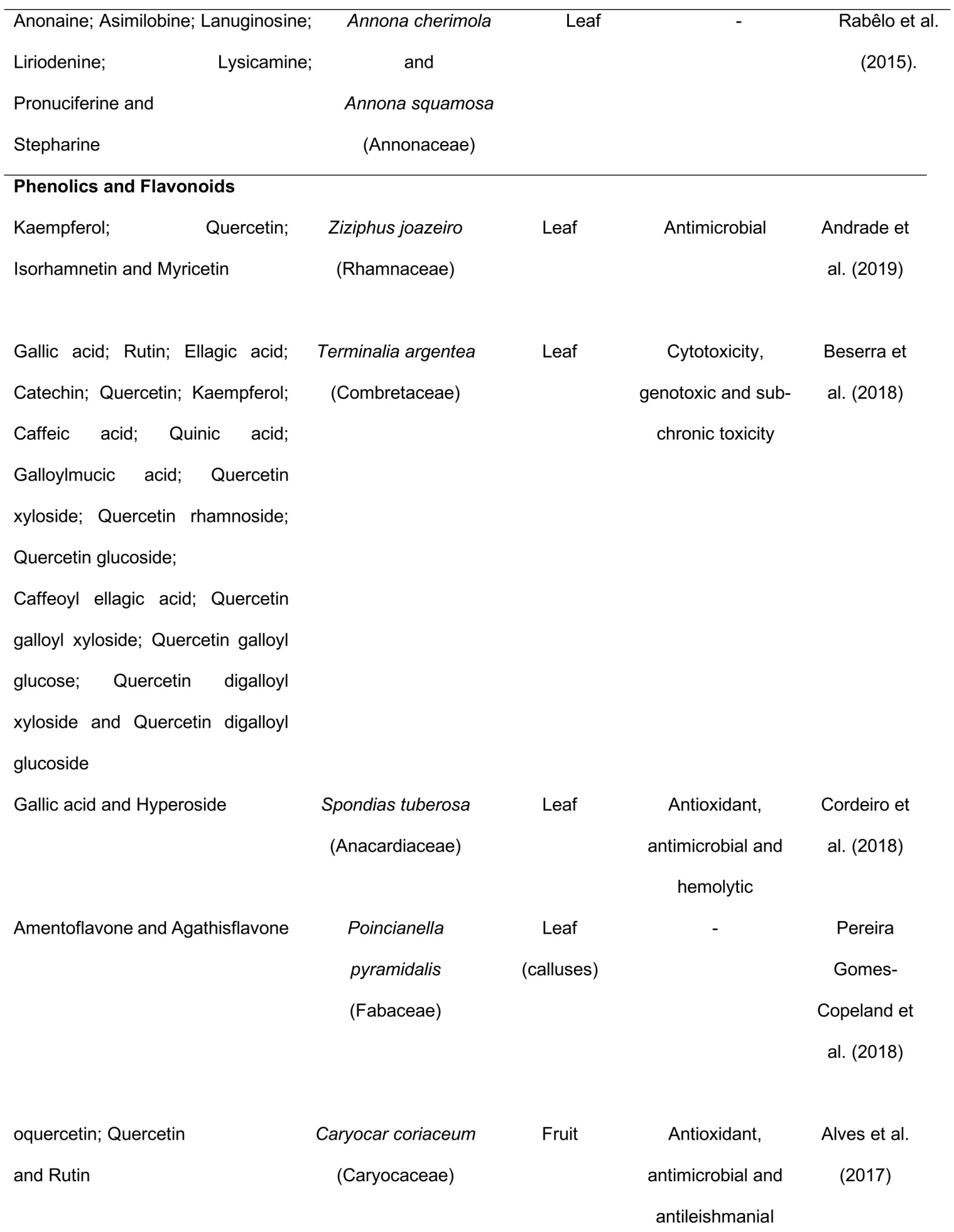

antileishmanial 


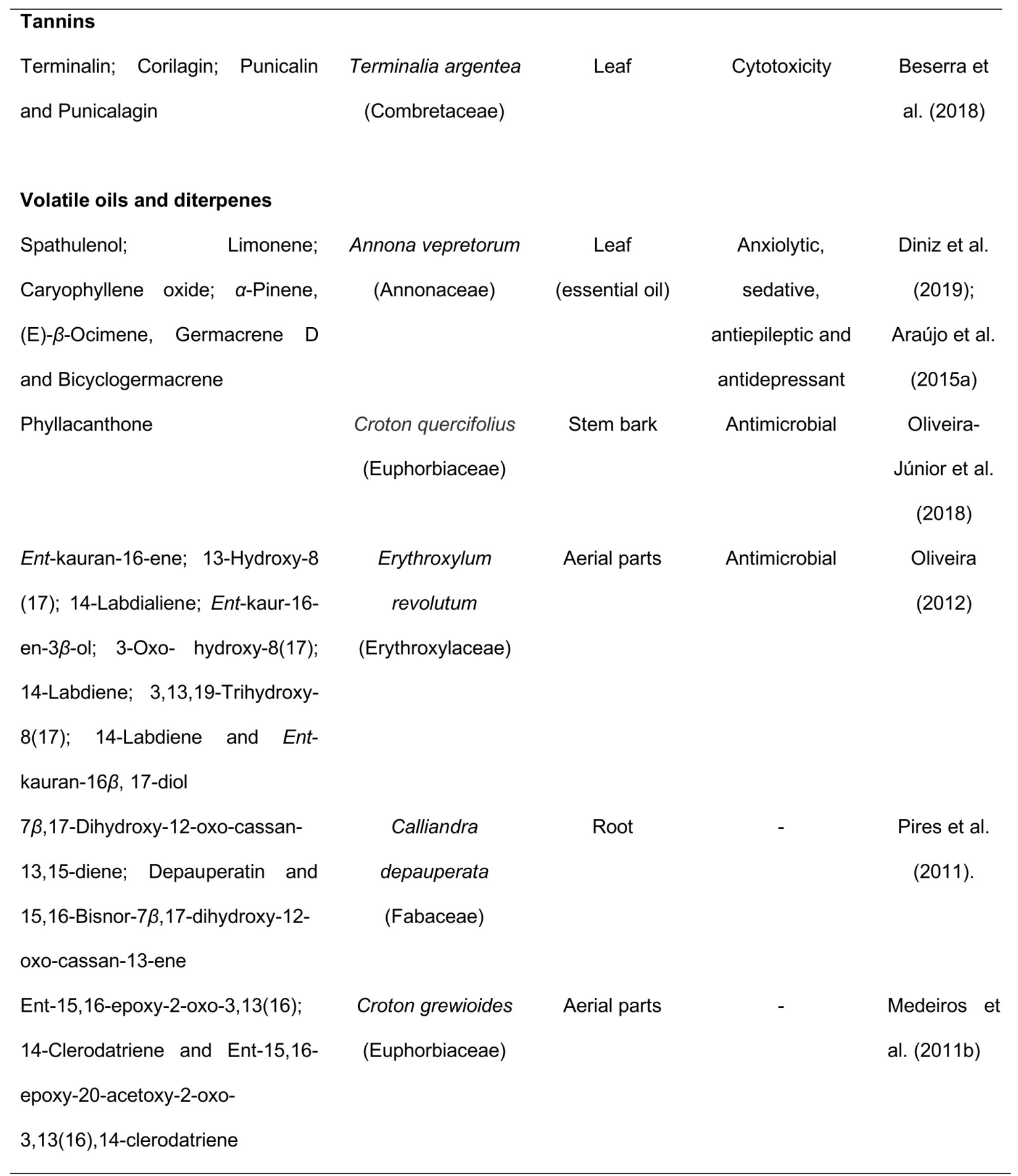




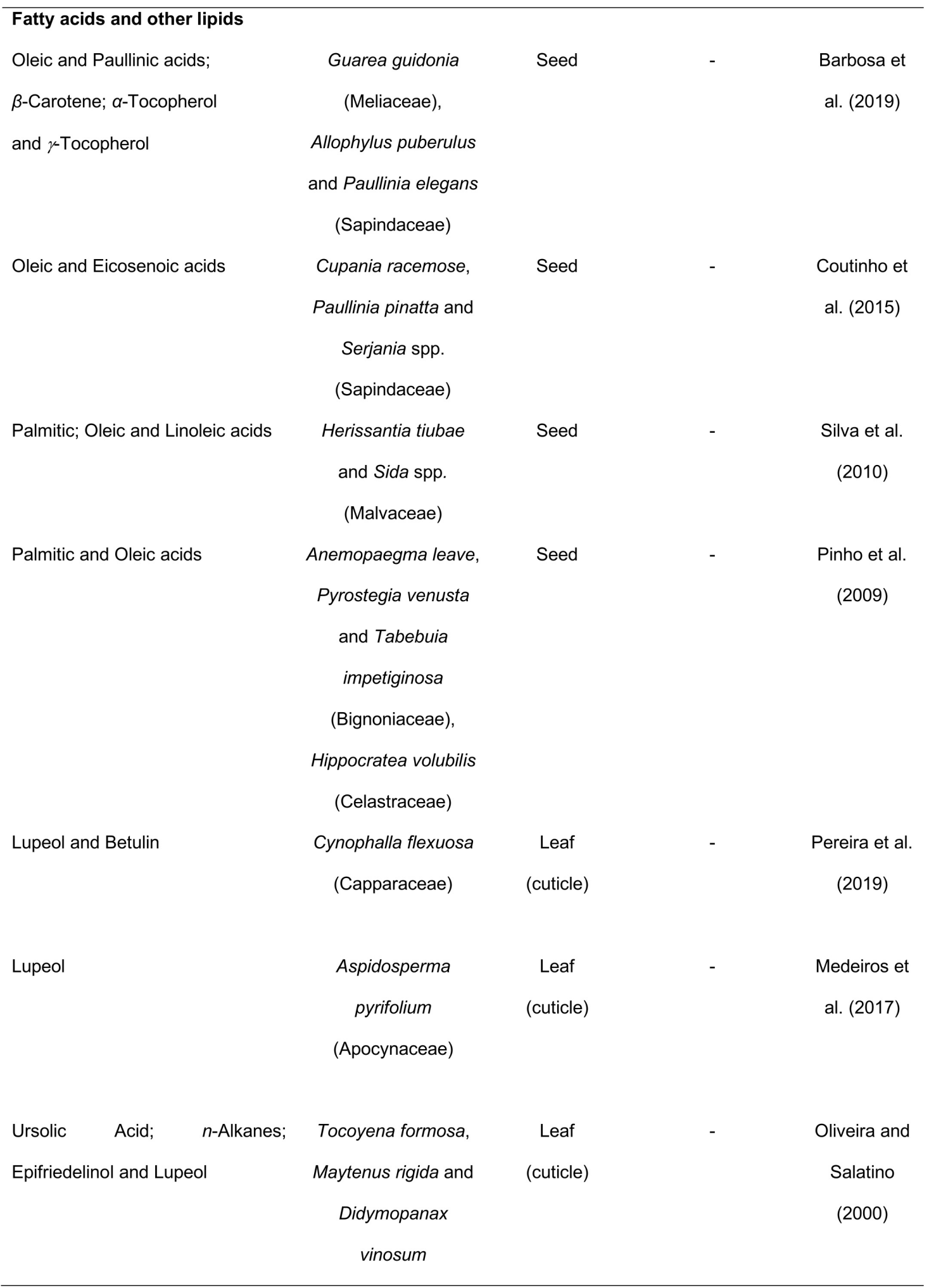

- not reported 
formation, which was higher in follicles cultured with plant extract than the control, and it also improved the cell viability, maturation and functionality (Barberino et al. 2016). Several culture media have been used to improve the rate of follicular viability and growth, although ovarian culture is too expensive. The use of $A$. cearensis is an interesting economic alternative that may make in vitro culture studies cheaper and more feasible for ovine and caprine animals (Barberino et al. 2016; Gouveia et al. 2016). A. cearensis may represent a very important biotechnology tool.

The extract of $A$. cearensis seeds was shown to have neuroprotective and antioxidant effects in cerebellar culture cells exposed to excitotoxic damage induced by glutamate. In addition, this species attenuated oxidative stress, reducing swelling, membrane potential dissipation, ROS production and calcium influx in isolated rat brains. Moreover, it induced the preservation of astrocytes, neurons and microglia in damaged rat brains (Lima Pereira et al. 2017). Parkinson's disease (PD) is reproduced in animal models via the injection of 6-hydroxydopamine (6-OHDA), a hydroxylated derivative of dopamine (Blum et al. 2001). Its neurotoxic action leads to oxidative stress (Tiffany-Castiglioni et al. 1982), catecholaminergic cell line apoptosis and activates nuclear factor-kappaB (NFkB) (Oh et al. 1995; Blum et al. 2001). Amburoside $\mathrm{A}$, a phenol glucoside derived from $A$. cearensis, acts as an antioxidant molecule and protects mesencephalic cells against 6-OHDA neurotoxicity (Leal et al. 2005).

Compounds isolated from $A$. cearensis, such as afromorsin, kaempferol, isokaempferide, amburoside $\mathrm{A}$, and protocatechuic have important biological effects, (Costa-Lotufo et al. 2003; Lopes et al. 2013; Leal et al. 2008). Specifically, afromorsin isolated from the extract of $A$. cearensis bark (EBAC) inhibited neutrophil degranulation, myeloperoxidase activity, TNF-a secretion, and ROS generation (Lopes et al. 2013). Amburoside A and isokaempferide, a flavonol, showed antiinflammatory activity and reduced the accumulation of inflammatory cells, myeloperoxidase activity and TNF- $\alpha$ production without cytotoxicity (Leal et al. 2009). These results show that $A$. cearensis is a good source of interesting molecules for the treatment of several diseases.

\subsection{Anadenanthera colubrina (Vell) Brenan}

A. colubrina, also known as "angico," is a tree belonging to the subfamily Mimosoideae (Leguminosae), and it occurs in different biomes and predominantly in seasonal forests and riparian galleries (Mota et al. 2017). A. colubrina is an important species to local communities in the Caatinga, and it is used for timber, charcoal and firewood as well as in popular medicine (Monteiro et al. $2006 a, b)$. Its products are employed to treat respiratory and lung infections, ulcerative external lesions, inflammation, diarrhea, cough, bronchitis, influenza, and toothache (Agra et al. 2008, 2007; Almeida et al. 2005; Araújo et al. 2008).

$\beta$-Sitosterol and $\beta$-sitosteryl linoleate were also isolated from the hexane-soluble fraction of $A$. colubrina fruits and exhibits intense antifungal effects against Alternaria alternata (Campos et al. 2014). Moreover, bufotenine, a well-studied alkaloid, has been isolated from $A$. colubrina seeds and is able to block rabies virus infection in BHK-21 cells (Vigerelli et al. 2014). In addition, tannins isolated from stem-bark extract from A. colubrina is able to impair Pseudomonas 
aeruginosa adhesion and biofilm formation (Trentin et al. 2013), and strong antifungal effects were demonstrated against Candida albicans. This extract also demonstrated the capacity to inhibit the formation of hyphae and blastospores, thus demonstrating the susceptibility of $C$. albicans biofilm to this plant. Although $A$. colubrina did not have a strong antiproliferative effect, it was capable of diminishing tumor growth in all cell lines (Lima et al. 2014). The antimicrobial effects of $A$. colubrina demonstrate the possibility of developing novel antifungal and antimicrobial agents from this plant. In addition, Barbosa et al. (2014) evaluated several extracts of native plants from Caatinga against Aedes aegypti and demonstrated that an extract from the seed of $A$. colubrina was adulticidal for insects (96\% died) but did not show toxicity in mammal cells.

Anti-inflammatory and antinociceptive effects of the aqueous extract of $A$. colubrina bark was demonstrated using rodent in vivo models. Mice subjected to acetic acidinduced writhing tests showed an improved peritoneal nociceptive response, which was partially because of the reduction of algogenic/hypernociceptive endogenous mediators, such as prostaglandins (PG), bradykinin (BK), serotonin (5-HT), and histamine (Le Bars et al. 2001; Santos et al. 2013). In addition, the hot plate test, a classical test used to evaluate the central pain process, revealed no effect of $A$. colubrina on central nociceptive pathways in mice. However, the anti-inflammatory effect of this plant was clearly demonstrated in carrageenan-induced paw edema and carrageenan peritonitis (Santos et al. 2013) because of a reduction in microvascular permeability and leukocyte influx and possibly because of a reduction in the formation and release of inflammatory mediators, such as histamine, BK,5-HT, PG, and others. The anti-inflammatory and peripheral antinociceptive effects of $A$. colubrina are consistently exerted across different pathways; however, the underlying mechanisms still need to be elucidated.

The positive effect of the hydroalcoholic extract of $A$. colubrina bark on the healing process of the skin of rats has been demonstrated. Wound treatment with this extract showed more organized granulation tissue, a higher concentration of typical fibroblasts, and greater collagen fiber and blood vessel contents (angiogenesis) at the 7th and 14th day after surgery when compared to the untreated group (Pessoa et al. 2012, 2015).

An interesting polysaccharide isolated from $A$. colubrina has been characterized as an immunomodulatory and antitumor molecule. A complex acidic heteropolysaccharide primarily containing galactose and arabinose (ARAGAL) was able to activate mice peritoneal macrophages in a time- and dose-dependent manner and promoted phagocytic ability and anion superoxide production (Moretão et al. 2003). The same research group subsequently reported that ARAGAL increased alpha tumor necrosis factor ( $\alpha$ TNF) levels, which is an important antitumor molecule, and killed sarcoma 180 cells both in vitro and in vivo (Moretão et al. 2004). Therefore, A. colubrina has a promising antitumor effect.

\subsection{Annona vepretorum Mart.}

A. vepretorum, which is popularly known in Brazil as "araticum," "bruteira" and "pinha da Caatinga," is a shrub or tree native to the Caatinga (Bomfim et al. 2016) that is widely used for human nutrition and medicinal purposes (Bomfim et al. 2016; Dutra et al. 
2014). The leaves are used in a decoction to treat allergies, skin diseases, yeast and bacterial infections, while its roots are indicated for the treatment of bee stings and snakes bites and as a sedative, antioxidant, antimicrobial, anti-inflammatory and pain treatment (Almeida et al. 2014b; Bomfim et al. 2016; Diniz et al. 2013; Dutra et al. 2014; Silva et al. 2015).

In addition, the crude ethanolic extract of A. vepretorum exerts antinociceptive and anti-inflammatory action in vivo under a chemically or thermally noxious stimulus. Mice treated with $A$. vepretorum show reduced acetic acid-induced writhing (Silva et al. 2015). A similar positive effect was detected in a formalin test, hot plate test and tail flick test. In general, these tests assess the central and peripheral nociceptive pathways (Le Bars et al. 2001), and the effects were blocked by naloxone, which might indicate that the antinociceptive effects are related to opioid receptor activation by the extract. Moreover, animals treated with A. vepretorum had better results in histamine and carrageenan hind paw edema models and showed reduced leucocyte migration in carrageenan-induced edema than untreated mice.

Several reports have shown that the Amona genus is a source of antitumor molecules (Formagio et al. 2015; Tundis et al. 2017; Zorofchian Moghadamtousi et al. 2014). The antitumoral activity of $A$. vepretorum has been associated with the essential oil (EO) from the leaves, especially spathulenol. The cytotoxic effect was also evaluated in peripheral blood mononuclear cells and B16-F10 melanoma cells with promising results. Spathulenol has been reported to be active against gastric adenocarcinoma cells (Areche et al. 2009), and it is a good candidate as an adjuvant chemotherapy. In addition, C57BL/6 mice inoculated with B16-F10 melanoma cells were treated consecutively for 11 days with the EO of spathulenol; in vivo tumor growth was inhibited by the treatment, and no toxic effects or hematological or peripheral blood biochemistry parameter changes were observed in mice (Bomfim et al. 2016).

Additionally, the leaf EO shows antioxidant, trypanocidal, antimalarial, antifungal properties. The antioxidant property of the EO from $A$. vepretorum (EOAV) was evaluated by two in vitro models, i.e., radical scavenging activity using the 1,1-diphenyl-2-picrylhydrazyl radical (DPPH) method and the $\beta$-carotenelinoleate model system, and it showed weak activity (Araújo et al. 2015a; Costa et al. 2012).

The EOAV demonstrated potent antimalarial activity against the erythrocytic stage of Plasmodium falciparum and a trypanocidal effect against Trypanosoma cruzi epimastigotes and trypomastigotes. In addition, an in vitro model of mouse macrophages infected with intracellular amastigotes, the chronic clinically relevant forms of $T$. cruzi showed that EOAV both significantly reduced the number of infected macrophages and the relative number of amastigotes per 100 macrophages (Meira et al. 2015). Trypanocidal action is mediated by plasma membrane alterations (sterol biosynthesis inhibition), severe mitochondrial swelling with a large loss of electron density from its matrix and induced necrosis (Meira et al. 2015). The intense trypanocidal activity could be attributed to the high concentration of bicyclogermacrene. Thus, EOAV had interesting results with low toxicity.

\subsection{Aspidosperma pyrifolium Mart.}

A. pyrifolium, which is popularly known as "pereiro," "pereiro preto" or "pereiro do 
sertão" (Araújo et al. 2007), has been used in folk medicine, such as for the relief of benign prostatic hyperplasia, diabetes, erectile dysfunction, would healing, dizziness and inflammation (Almeida et al. 2019; Souza Lima and Soto-Blanco 2010; Souza Lima et al. 2017).

The anti-inflammatory effects of the aqueous extract of $A$. pyrifolium leaves were evaluated in carrageenan-induced and Tityus serralutus scorpion venom-induced peritonitis models. This extract was able to prevent inflammation and reduce leukocyte migration (Souza Lima et al. 2017). The mechanisms involved in envenomation by $T$. serralutus involved local leucocyte migration, sodium and potassium ions in excitable cells, nitric oxide and cytokine mediators (Martin-Eauclaire et al. 2018; Pucca et al. 2015). Thus, $A$. pyrifolium may modulate ion channels and pro-inflammatory mediator synthesis. The phytochemical profile revealed the presence of a large amount of flavonoids and phenolic derivatives in the hydroalcoholic extract of $A$. pyrifolium. Recently, the neuroprotective and antioxidant properties of this extract were demonstrated in rats (Araújo et al. 2018). The extract of $A$. pyrifolium seeds blocked the behavioral changes in a rat model of PD, such as apomorphine-induced rotation, motor incoordination and degeneration of dopaminergic tonus (Araújo et al. 2018). Araújo et al. (2018) showed that rats treated with $A$. pyrifolium extract presented reduced nitrite levels and lipid peroxidation in lesioned striatum. These authors also showed the reduction of TNF-alpha content in the striatum, thus confirming the antiinflammatory effect of this species.

Malaria is a major parasitic infection in many tropical and subtropical regions, and it still remains one of the leading causes of death worldwide (WHO 2017, 2018).
Plasmodium vivax is the most common cause of malaria in Latin American, and it has developed resistance to the antimalarial drug Chloroquine (Rahman et al. 2019). Several plants have been used to treat malaria. The ethanolic crude stem-bark extract of $A$. pyrifolium showed high antimalarial activity with low in vitro toxicity (Ceravolo et al. 2018). The beneficial biological effects have been associated with the presence of monoterpenoid indole alkaloids, such as aspidofractinine and 15demethoxypyrifoline (Araújo et al. 2007), and another report showed that the ethanolic extract of $A$. pyrifolium leaves caused hemolysis, lethality to 1-day-old Artemia salina larvae, and abortion, low fetal birth weight and high toxicity in Wistar pregnant rats (de Souza Lima and Soto-Blanco 2010). Previous reports showed that embryonic death, abortion and premature birth were induced by $A$. pyrifolium in farm animals (de Souza Lima and Soto-Blanco 2010; RietCorrea et al. 2012).

\subsection{Cnidoscolus quercifolius Pohl}

C. quercifolius, which is popularly named "favela" or "faveleira," is a native forage species of the Caatinga that produces latex, can be used to recover degraded areas; provide food for animal and human consumption; and as medicine, timber, and energy (de Araújo Gomes et al. 2014; Paredes et al. 2016). Considering folk medicine, $C$. quercifolius is also used to treat inflammation (Lorenzi and Matos 2002; Maia-Silva et al. 2012). Reports about the pharmacological effects of this species are scarce. The genus Cnidoscolus is used for several medicinal purposes, including as an anti-inflammatory, an antitumor agent for the genitourinary system, an antiseptic and to treat kidney infections, dermatological and 
ophthalmic lesions, bruises, fractures, wounds, warts, dysentery, hemorrhage, appendicitis and rheumatism (Albuquerque et al. 2007; Almeida et al. 2005; José et al. 2012).

The popular use of $C$. quercifolius extract to treat inflammation is supported by its antiinflammatory activity as demonstrated in carrageenan-induced paw edema and peritonitis inflammation models in mice. The anti-inflammatory effect of the ethanolic extract of $C$. quercifolius is at least partially because of the inhibited synthesis of inflammatory mediators including prostaglandins, histamine and neutrophils (de Araújo Gomes et al. 2014). The crude extract from the bark of $C$. quercifolius is efficient against Staphylococcus epidermidis (AM235), an important bacteria involved in severe infection, including endocarditis and sepsis, as well as routine clinical procedures, such as catheter implantation (José et al. 2012). However, this extract inactive against gram-negative bacteria.

The aqueous extract of $C$. quercifolius did not present an acute toxic effect because physical, behavioral or motor changes were not observed, none of the treated animals died, and the organ weight of the treated mice did not change. However, this extract exerts a hypoglycemic effect in diabetic streptozotocin-induced mice (Lira et al. 2017) and has antioxidant properties (Ribeiro et al. 2017).

\subsection{Erythrina velutina Willd}

E. velutina is an endemic tree to the plains and riverbanks of Northeast Brazil, and it is popularly called "mulungu." This tree is well known for its effects on the central neural system, such as sedation, insomnia, convulsions (Dantas et al. 2004).

The antinociceptive effect of the hydroalcoholic extract of $E$. veluntina stem bark was demonstrated by the reduction of abdominal pain induced by acetic acid independent of the opioid system in mice, and this effect was primarily caused by antiinflammatory action (Vasconcelos et al. 2003). Curiously, Marchioro et al. (2005) showed that the ethanolic extract of $E$. veluntina leaves had antinociceptive effects and was dependent on the opioid system.

The use of $E$. velutina to treat others central nervous system (CNS) disturbances has been demonstrated. The hydroalcoholic extract of $E$. velutina stem bark exerts anxiolytic-like effects in rats (Raupp et al. 2008; Ribeiro et al. 2006), anticonvulsant activity (Vasconcelos et al. 2007), attenuation of schizophrenia-like behavior (Dias KCF et al. 2019; Ximenes et al. 2018), antioxidant effects (Dias KCF et al. 2019; Silva et al. 2016) and neuroprotective effects against 5-6-hydroxydopaimine-induced neurotoxicity (Silva et al. 2016) and acute cerebral ischemia (Rodrigues et al. 2017). In addition, the indole alkaloid hypaphorine isolated from $E$. velutina induces sleep in normal mice. Taken together, these results confirm the effect of this species on the CNS, which is reflected in the traditional knowledge of this species.

\subsection{Lippia origanoides Kunth}

L. origanoides is an aromatic shrub popularly known as "erva-do-marajó," "alecrim-angola," "alecrim pimenta," "orégano," "orégano do monte," or "salva-domarajó" (Brito FCR et al. 2018; Menezes et al. 2018; Raman et al. 2017). The leaves are used as seasoning, and its tea is used as a sedative and to treat gastrointestinal disease; infections of the throat, skin, and scalp; pain; and asthma (Menezes et al. 2018; Oliveira et al. 2014). 
The ethanolic extract of $L$. origanoides leaves demonstrate an acaricidal effect against Tetranychus cinnabarinus and the potential for the biological control of pests (Sivira et al. 2011). In addition, an extract of $L$. origanoides leaves was able to inhibit the progression of aggressive breast cancer cells (Raman et al. 2017), which was partially associated with its ability to trigger the rapid irreversible apoptosis of cancer cells by reducing mitochondrial oxidative metabolism and ATP levels (Raman et al. 2018). The biological effect of this species is associated with its EO. In fact, the EO of $L$. origanoides (EOLO) has antimicrobial (Hernandes et al. 2017), trypanocidal (Baldissera et al. 2017) and insecticidal activity (Vera et al. 2014) because of its chemical composition, which is predominantly terpenoids compounds, including monoterpenes, such as carvacrol, p-cymene, linalool, thymol, and carvophyllene (Menezes et al. 2018).

In addition, EOLO has a relaxant effect on trachea smooth muscle, which is related to its ability to modulate potassium channels and soluble guanylyl cyclase (Menezes et al. 2018). The secondary metabolite profile of EOLO showed at least 91 different compounds of $L$. origanoides such as limonene, $\beta$-myrcene, naringenin, luteolin, quercetin, trans- $\beta$-ocimene and linalool, which are common in EO (Stashenko et al. 2013). In addition, this profile included wellknown antimicrobial and antioxidant molecules and promoted adipose tissue proliferation (Brito FN et al. 2018; Stashenko et al. 2013). Carvracol and thymol have been associated with the genoprotective effect of L. origanoides (Vicuña et al. 2010).

\subsection{Myracrodruon}

\section{Allemão}

M. urundeuva is a tree widely distributed in the Caatinga in the semi-arid region of Northeast Brazil. It is popularly named "aroeira" or "aroeira do sertão" and is used in folk medicine to treat gynecological infections and as an anti-inflammatory agent (Oliveira et al. 2017; Viana et al. 2003). Unfortunately, this species is threatened with extinction and has been highly exploited as a timber source and fuel (Soares et al. 2018).

The anti-inflammatory effect of $M$. urundeuva has been proved in several models. Enemas of $M$. urundeuva reduce the number of inflammatory cells and increased the reepithelization of tissue without fibrosis in a colitis model induced by acetic acid (Rodrigues et al. 2002). The aqueous extract of $M$. urundeuva leaves reduced Streptococcus mutans accumulation and prevented enamel demineralization and caries in rats (Crivelaro de Menezes et al. 2010). Matos et al. (2019) showed that the $M$. urundeuva extract modulates mineral bone metabolism. In addition, the ethanolic, ethyl acetate and hydroalcoholic extracts of $M$. urundeuva bark and leaves showed no hemolytic, genotoxic, mutagenic or toxic effects in rats. In addition, the $M$. urundeuva bark extract has a potential effect against $C$. albicans. These effects are associated with the presence of flavonoids and tannins (Oliveira et al. 2017). In addition, the chalcone-enriched fraction had a beneficial effect on periodontal disease in rats (Botelho et al. 2008).

Neuroprotection is another important beneficial effect of $M$. urundeuva, and this activity is associated with the antioxidant and anti-inflammatory effect of the extract, thus indicating its potential use as a tool to prevent or treat neurodegenerative states, such as PD (Calou et al. 2014). The chalcone-enriched fraction isolated from the M. urundeuva stem bark had a protective 
effect on the CNS, including reduced oxidative stress and apoptotic injury induced by 6-hydroxydopamine in mesencephalic cells (Nobre-Júnior et al. 2009). In this context, the dimeric chalcones derived from of $M$. urundeuva presents inhibitory activity against cathepsins $\mathrm{V}$, which is important because this enzyme is involved in several physiological and pathological processes, including the development of neurological disorders (Niwa et al. 2012; Sarria et al. 2018).

The tannin-enriched fraction derived from the stem bark of $M$. urundeuva has both anti-inflammatory and antiulcer gastric action in mice, which is because of its antioxidant properties and presence of polyphenols (Souza et al. 2007). These results were confirmed in several experimental models, such as ethanol-induced gastric lesions and croton oil-induced ear edema in rats (Aguiar Galvão et al. 2018). The antinociceptive and anti-inflammatory effects of the dimeric chalcone-enriched fraction derived from the stem-bark ethyl acetate extract of $M$. urundeuva was reported in a mouse model (Viana et al. 2003). Taken together, these data confirmed the traditional uses of this species.

The anthelmintic and insecticidal effects of $M$. urundeuva have been demonstrated. Recently, Soares et al. (2018) showed the anthelmintic activity of the extract of $M$. urundeuva seeds against Haemonchus contortus. An extract of the leaf and stem of M. urundeuva also efficiently inhibited egg hatching and larval exsheathment of $H$. contortus (de Oliveira et al. 2011). Moreover, lectins isolated from this species had larvicidal effects (Sá et al. 2009), and pentadecadienyl-phenol had insecticidal effects against Aedes aegypti (Souza et al. 2012). Taken together, the data show that $M$. urundeuva is a source of beneficial molecules with therapeutic potential.

\subsection{Spondias tuberosa Arruda}

S. tuberosa, which is popularly known as "umbu" or "imbu," is an endemic species to the Caatinga that is widely used as a medicinal plant for the treatment of colic, diarrhea, diabetes mellitus, menstrual disturbances, placental delivery, inflammation, renal infection, and throat afflictions, and it is also used as an antiemetic and tonic (Silva et al. 2012a; de Albuquerque et al. 2007; de Freitas LinsNeto et al. 2010; Araújo et al. 2012). The occurrence of phenols, hydrolysable tannins, flavones, flavonoids, leucoanthocyanidins in the Spondias genus has been well described. Phenols, tannins, triterpenes and quinones were detected in an ethanolic extract of the inner bark (Almeida et al. 2005), and the flavonoid and tannin content has been quantified in a methanolic extract of the bark (Araújo et al. 2008). HPLC analysis of a methanolic extract of $\mathrm{S}$. tuberosa leaves performed by Silva et al. (2012a) showed the occurrence of high amounts of rutin, quercetin, and ellagic acid. The chlorogenic acid, caffeic acid, rutin and isoquercitrin contents were quantified in a hydroethanolic extract of leaves from $S$. tuberosa. Although $S$. tuberosa has been extensively used in folk medicine, pharmacological studies on this species are scarce in the literature.

The anti-inflammatory activity of $S$. tuberosa extract has been demonstrated via different experimental protocols using a carrageenan-induced paw edema model as well as a peritonitis animal models (Silva Siqueira et al. 2016). S. tuberosa extract reduces the influx of neutrophils in mice paw tissues and decreases myeloperoxidase (MPO) activity and leukocyte counts in the 
peritoneal fluid after carrageenan challenge (Siqueira et al. 2016). These effects were similar to that of dexamethasone treatment, which is a standard anti-inflammatory drug. The antibacterial activities of $S$. tuberosa extract were assayed against eight gramnegative bacteria in vitro by the agar well diffusion method (Silva et al. 2012a). In general, the data showed a weakly antibacterial effect of $S$. tuberosa via determination of the minimum inhibitory concentration (MIC). Although the activities of $S$. tuberosa were reduced compared with that of ciprofloxacin, a standard antibiotic, the increased resistance of microorganisms to antibiotics must be considered to promote the search for new drugs. Interestingly, the hexane extract of $S$. tuberosa leaves had a potent antifungal effect (low value of MIC50) via the mitochondrial overproduction of anion superoxide and hyperpolarization of the mitochondrial membrane (da Costa Cordeiro et al. 2018). Recently, the antidiabetic effect of $S$. tuberosa was detailed (Barbosa et al. 2018). A hydroethanolic extract of the inner stem bark of $S$. tuberosa attenuated hyperglycemia and glucose oral tolerance and improved insulin sensitivity in diabetic streptozotocin-induced rats. In addition, $S$. tuberosa had important antioxidant and hepatoprotective effects in diabetic models (Barbosa et al. 2018).

The antioxidant activity of $S$. tuberosa has been shown in vitro (Silva et al. 2012a; Cordeiro et al. 2018) and in vivo (Barbosa et al. 2018). The antioxidant activity was evaluated by scavenging the radicals DPPH and 2,2-azino-bis (3-ethylbenzthiazoline-6sulfonic acid) (ABTS•+), which demonstrated a weak and moderate effect (Cordeiro et al. 2018). In addition, S. tuberosa exerted a potent in vivo antioxidant effect, reduced lipid peroxidation, improved enzymatic defense and increased the antioxidant status in diabetic rats (Barbosa et al. 2018). These effects are consistent with phytochemical constitution of $S$. tuberosa.

An acute toxicity and cytotoxicity evaluation of $S$. tuberosa inner bark extract showed the absence of poisonous effects (Barbosa et al. 2016), which demonstrates that this species may be safely used as therapeutic alternative in the treatment of several diseases.

\subsection{Ximenia americana $\mathrm{L}$.}

$X$. americana is a bushy or small tree popularly known as "ameixa," and it is distributed in Africa, Asia and tropical America. In traditional medicine, the leaves and bark of $X$. americana are used in a tea to treat pain, obesity, dysmenorrhea, inflammation, wound healing, diabetes, cough, hoarseness, constipation, venereal disease, leprotic ulcer, skin diseases, malaria and osteoporosis (Diallo et al. 2002; Grønhaug et al. 2008; Le et al. 2012; Ogunleye and Ibitoye 2003; Bitu et al. 2015).

$X$. americana has antiviral activity against HIV-1 (Asres et al. 2001). In addition, this species has been used as an herbal medicine by persons living with HIVIAIDS in Africa to ameliorate HIV/AIDS-related symptoms and HIVIAIDS infection (Nagata et al. 2011).

The potent anticancer activity of $X$. americana aqueous extracts has also been observed (Voss et al. 2006b). In addition, riproximin, a type II ribosome-inactivating protein, was isolated from $X$. americana fruits and seeds and shows high selectivity for tumor cell lines (Bayer et al. 2012). Riproximin (RPX) was able to inhibit protein synthesis in a cell-free system and is toxic to HeLa cells. This antineoplastic effect was confirmed in vivo in a CC531 colorectal cancer rat model and in humans (Pervaiz et 
al. 2015; Voss et al. 2006a). In addition, RPX induced important cytotoxic effects in the selected human breast cancer cell lines MDA-MB-231 and MCF-7 by modulating cytostatic and apoptotic pathways (Pervaiz et al. 2016). RPX was able to inhibit pancreatic cancer metastasis to the liver in rats bearing intraportal implanted Suit2-007 cells (Adwan et al. 2014).

The aqueous extract of $X$. americana elicited a potent analgesic effect on inflammatory pain but possessed a weak effect on central nociceptive pathways (Soro et al. 2016). These effects are related to the anti-edematogenic effect of the hydroalcoholic extract of $X$. americana on acute and chronic inflammation, which likely inhibits inflammatory mediators (Silva et al. 2018). Moreover, the hydroalcoholic extract of $X$. americana showed angiogenic effects and stimulated collagen synthesis to accelerate wound healing in rats (Souza Neto Júnior et al. 2019) and antidiabetic activity (Siddaiah et al. 2019). The tanninrich extract of $X$. americana has hepatoprotective and antidiabetic properties (Sobeh et al. 2017). The gastroprotective effect has been confirmed in other gastric ulcer models, and this protection is mediated by sulfhydryl, nitric oxide and antisecretory activity, which is correlated with its major constituents, procyanidins $\mathrm{B}$ and $\mathrm{C}$ and catechin/epicatechin (Aragao et al. 2018).

In addition, the heteropolysaccharideenriched fraction of $X$. americana bark had anti-inflammatory and analgesic effects in an experimental model of caerulein-induced acute pancreatitis, and they involved type 2 carabinoid receptors (Silva-Leite et al. 2018). Moreover, a polysaccharide-rich tea of $X$. americana bark protected against indomethacin-induced gastric injury mice, which was likely associated with a reduction of neutrophil infiltration (Silva Pantoja et al.
2018).

It is noteworthy that pharmaceutical technology has been used to improve natural products for treatment purposes; for example, a tablet of $X$. americana was developed from mucoadhesive polymers for the oral treatment of fungal infection (Almeida et al. 2019).

\subsection{Ziziphus joazeiro Mart.}

Z. joazeiro (Rhamnaceae) is a native tree widely distributed in northeastern Brazil (Lucena et al. 2008) and the Caatinga biome, where it is named "juazeiro." It is used traditionally in folk medicine for treating fever, bacterial infection, general pain, gingivitis, and respiratory diseases; for topical healing; and as a hepatic and cardiac tonic; as a diuretic; and for other purposes (Brito et al. 2015).

The antipyretic effect of $Z$. joazeiro was demonstrated in endotoxemic rabbits (Nunes et al. 1987), and a low antioxidant effect was also reported based on the scavenging of the radical DPPH (Silva et al. 2011; Brito et al. 2015) and ferric reducing ability of plasma assay (Brito et al. 2015).

\subsection{Antimicrobial activity}

A great number of papers on the antimicrobial activity of plants in the Caatinga are being accumulated. Most of them are studies with crude extracts and show activities that can be considered irrelevant, since they are carried out with extracts in high concentrations. In Table 2, we present 18 plant species that showed antimicrobial activity $\leq 1000 \mu \mathrm{g} / \mathrm{mL}$ against the microorganisms tested. Based on these data, most of the results were obtained with extracts at high concentrations and thus are not very interesting for future 
pharmacological studies (according to Ríos and Recio 2005).

The strains that were most susceptible to extracts at $\leq 1000 \mu \mathrm{g} / \mathrm{mL}$ concentrations were the Gram-positive Staphylococcus aureus, which was susceptible to extracts of 11 plant species; Micrococcus luteus, which was inhibited by the extracts of seven species; and the gram-negative $P$. aeruginosa, which was inhibited by four extracts (see Table 2). The bacteria reported as being more susceptible to extracts were also the most registered in the studies (>20 publications), with the exception of the bacteria M. Iuteus. Escherichia coli was the most commonly used in laboratories to test the sensitivity of plant extracts (25 publications). However, only extracts from $A$. vepretorum and $S$. brasiliensis presented good activity $(\leq 1000)$ (Almeida et al. 2014b; Saraiva et al. 2011).

The extracts of the species that presented activities at very low concentrations (MICs $\leq 100 \mu \mathrm{g} / \mathrm{mL}$ ) were the methanolic extract of the leaf of Shinopsis brasiliensis, which presented an effect on the strains of $P$. aeruginosa and $S$. aureus at a very low concentration (31 $\mu \mathrm{g} / \mathrm{mL})$ (Saraiva et al. 2011). Additionally, the methanolic extract of $C$. quercifolius inhibited the growth of Enterococcus faecalis, Enterococcus faecium, Lasiodiplodia theobromae, P. aeruginosa, S. epidermidis and the fungus Colletotrichum gloeosporioides at concentrations of 7-62 $\mu \mathrm{g} /$ $\mathrm{mL}$ (Paredes et al. 2016) (Table 2). Plant extracts that showed a broad spectrum of activity $(\leq 1000)$ were those of Buchenavia tetraphylla (Aubl.) R.A. Howard, Poincianella pyramidalis (Tul) L.P. Queiroz, Senna macranthera (Collad.) H.S. Irwin \& Barneby, and Shinopsis brasiliensis Engl. (Table 2).

Only a few extracts $(2 \%$ of all tested extracts $[n=174]$ ) inhibited fungal growth.
For this group, the most recorded species in the studies was $C$. albicans, which was more susceptible to the plant extracts (Cruz et al. 2007; Silva et al. 2011, 2012b). An aqueous extract of the leaf of $C$. pyramidalis, an aqueous extract of the bark $Z$. joazeiro and an ethanolic extract of the leaf and bark of $Z$. joazeiro presented antimicrobial action at low concentrations ranging from $6-25 \mu \mathrm{g} / \mathrm{mL}$, and they also presented broad spectra of action against the fungi $C$. albicans, Candida guilliermondii, Cryptococcus neoformans, Fonsecaea pedrosoi, and Trichophyton rubrum (Cruz et al. 2007).

The low number of active extracts against fungi may reflect the difficulty of finding active extracts for this group. Owing to the complexity of fungal cells, finding substances that are both selective against a specific target and provide a safe antifungal effect is difficult. This limitation coupled with the limited research on plants for antifungal activity compared to antibacterial activity has been a barrier in the search for new natural antifungal products. Thus, the results indicate the need for in vitro studies to discover new alternatives for fighting fungi.

Newman and Cragg (2016) surveyed antimicrobial sources and observed the lack of new antifungal agents obtained from natural products from 1981 to 2014. This study found that compared with antibacterial agents, antifungal agents were predominantly of synthetic origin, with $73 \%$ of the antibacterial agents obtained from natural products, while only $10 \%$ of the antifungals are from natural products. These data are of concern because of the urgent need to obtain new products since many have lost their effectiveness.

In general, in the tests evaluated by the disc-diffusion method in agar, the concentrations were very high when compared to those of the microdilution 
Table 2. Native Caatinga plants with antimicrobial activity at concentrations of $\leq 1000 \mu \mathrm{g} / \mathrm{ml}$.

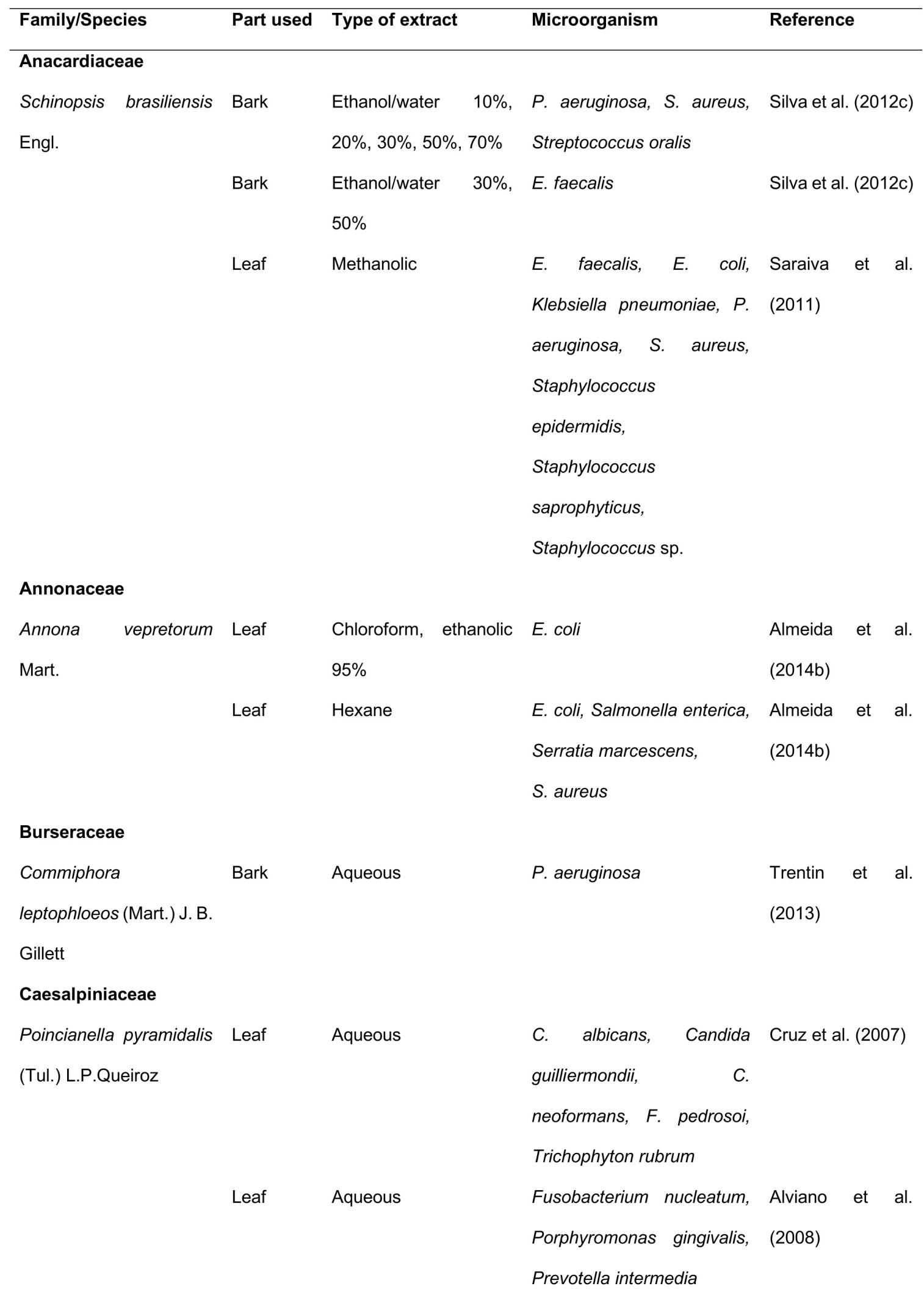




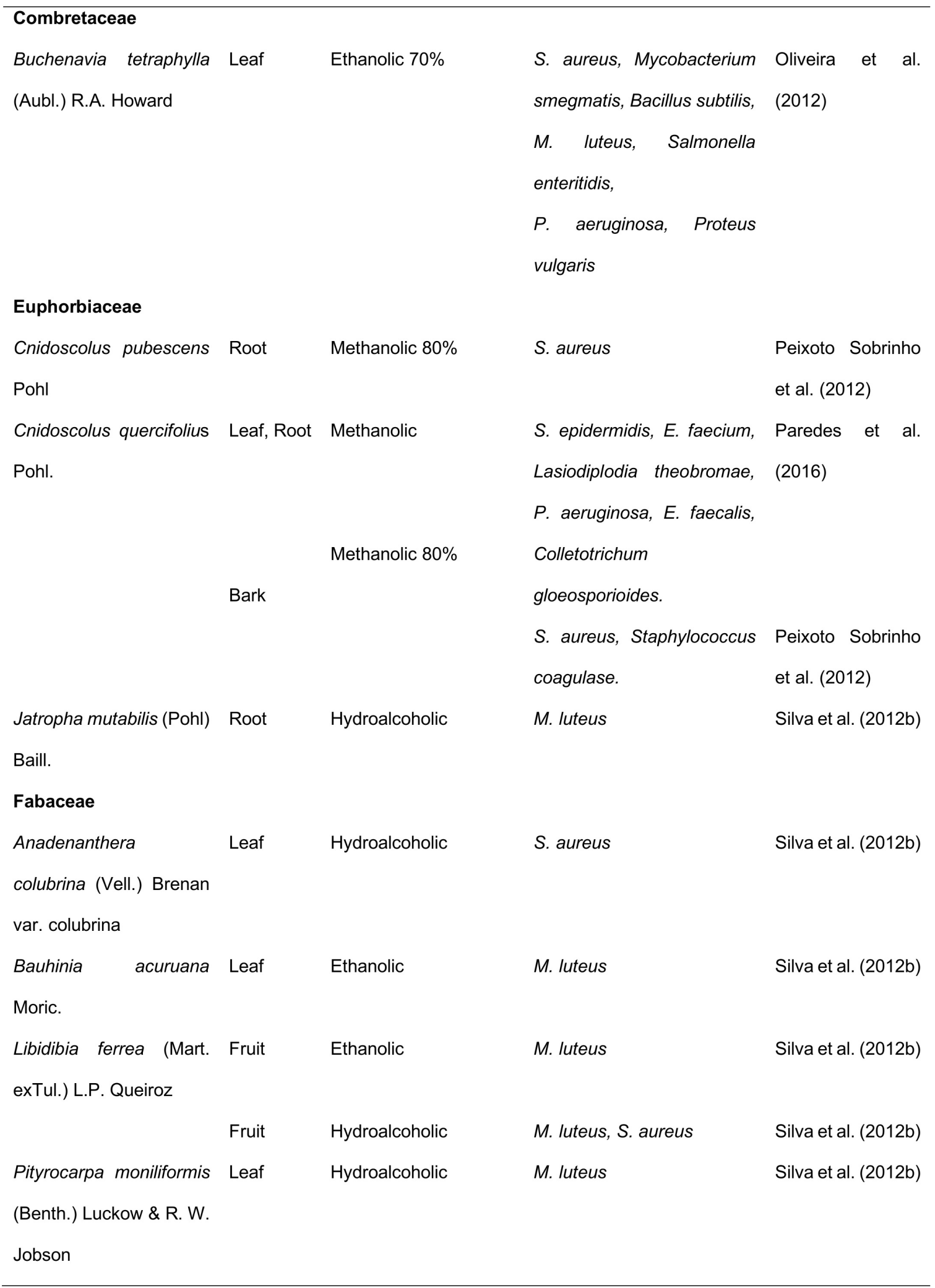




\begin{tabular}{lllll}
\hline Senna macranthera & Flower & Ethanolic & S. aureus & Diaz et al. (2010) \\
(Collad.) H.S. Irwin \& & & & \\
Barneby & Root & Dichloromethane, & S. aureus, Streptococcus Andrade et al. \\
& & ethanol & agalactiae, Streptococcus (2015)
\end{tabular}

Sw.

Malpighiaceae

Stigmaphyllon paralias Leaf Hydroalcoholic S. aureus $\quad$ Silva et al. (2012b)

A. Juss.

\section{Myrtaceae}

Eugenia brejoensis Leaf Hydroalcoholic C. albicans, M. luteus Silva et al. (2012b)

Mazine

\section{Olacaceae}

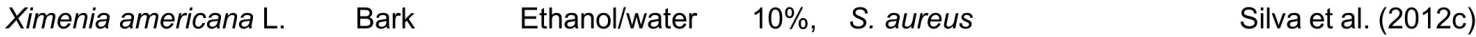
$20 \%, 30 \%, 50 \%$

$\begin{array}{llll}\text { Bark } & \text { Ethanol/water } 30 \% & \text { E. faecalis } & \text { Silva et al. (2012c) } \\ \text { Bark } & \text { Ethanol/water } 70 \% & \text { S. oralis } & \text { Silva et al. (2012c) }\end{array}$

\section{Rhamnaceae}

Ziziphus joazeiro Mart. Bark Ethanolic

B. subtilis, C. albicans, Silva et al. (2011)

Enterobacter aerogenes, E.

faecalis, K. pneumoniae, $M$.

luteus, M. smegmatis,

Proteus mirabilis, $P$.

vulgaris, S. marcescens, $S$.

aureus, Streptococcus

pyogenes

$\begin{array}{lll}\text { Inner bark Aqueous } & P \text {. gingivalis Alviano et al. }\end{array}$ 


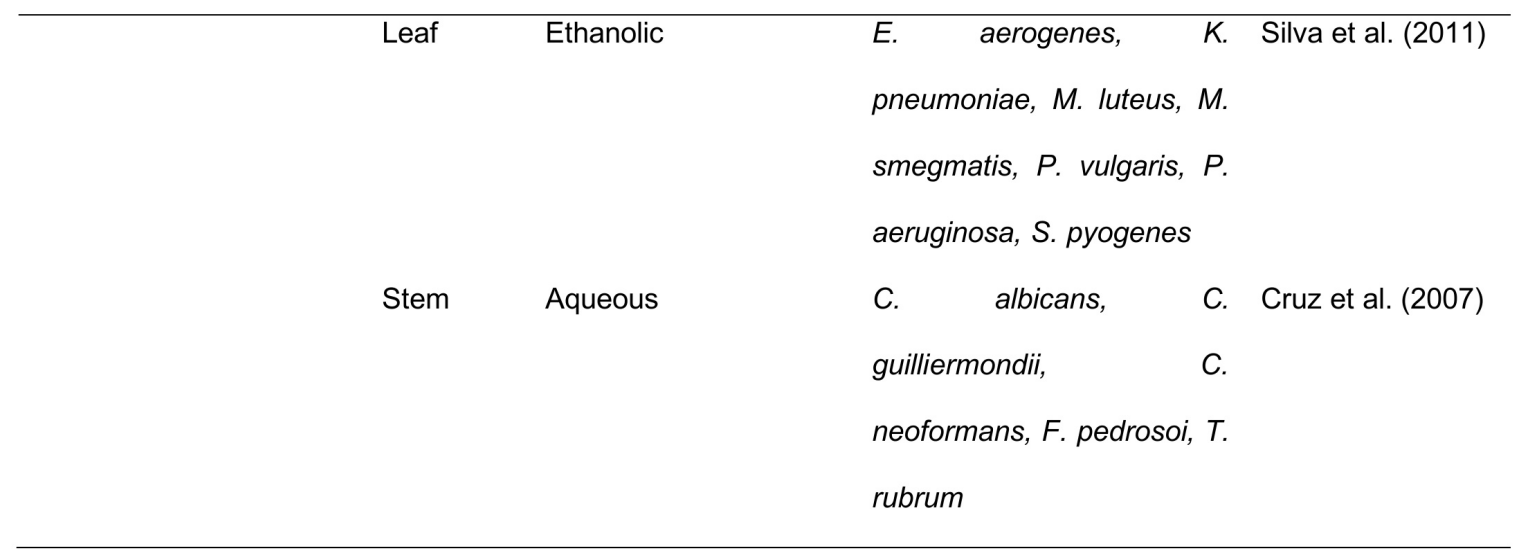

method, which is common in such studies (Braga 2016). It is reasonable that there are differences in the concentrations used for both tests, since they employed different techniques. However, excessively high amounts should be avoided to optimize the search for extracts with better activities for more detailed future studies. The extremely high doses applied in the trials have shown that there is a need to relativize the findings since they do not determine the activity of a plant. Therefore, it is suggested that new microdilution assays should be performed for the extracts that were evaluated only by diffusion, since this technique is the most recommended for determining antimicrobial activity (Alves GA et al. 2008).

\section{Zoopharmacognosy Zoopharmacology in the Caatinga}

A study by Ferreira et al. (2010) indicated that research describing the chemical composition and pharmacological effects of remedies obtained from animal parts are still scarce. In the Northeast Brazil, bioprospecting has contributed to the identification and elucidation of the therapeutic effects of chemical compounds that may be present in zootherapies, which are frequently used for the empirical treatment of different health conditions (Alves and Rosa 2005, 2006, 2007a, 2007b, 2007c; Alves et al. 2007; Cabral et al. 2013; Dias et al. 2013; Oliveira et al. 2014; Sales et al. 2015).

Reptiles and amphibians are among the most frequently studied wild species in the Caatinga in terms of their chemical compositions, especially in studies that aim to identify and/or isolate compounds present in extracts obtained from body fat and secretions (such as saliva and venom). Moreover, ethnozoology surveys have shown that reptiles are among the most commonly used animal species in folk medicine (Zhou and Jiang 2004; Mahawar and Jaroli 2006, 2008; Alves and PereiraFilho 2007; Alves et al. 2008a, 2008b) and show that body fat stands out as one of the most commonly used products (Costa-Neto and Alves 2010; Alves and Alves 2011).

Studies performed with reptiles from the Caatinga a predominantly investigate the chemical composition and pharmacological properties of secretions obtained from venomous snakes. A new bradykininpotentiating peptide was identified and isolated (Pro-Asn-Leu-Pro-Asn-Tyr-Leu-Glylle-Pro-Pro) from the venom extracted from Crotalus durissus cascavella. When investigated for its pharmacological 
potential, the effects of this peptide were compared to that of the potentiated bradykinin peptide (BBP9a) isolated from Bothrops jararaca and the antihypertensive drug captopril@ (Lopes et al. 2014). Studies with the Crotalus durissus collilineatus species have identified and isolated factors with potent central analgesic activity that possibly act on the opioid system. Gomes (2007) isolated an analgesic factor called crotamine from $C$. durissus poison; in this study, the author observed that crotamine in natura or after heat treatment (boiling at $100^{\circ} \mathrm{C}$ for 8 minutes) was effective at reducing algic stimuli in mice and exhibited a potency greater than morphine with a longer lasting effect. Olinda (2010) isolated an analgesic factor (Cdc factor) from $C$. durissus and observed that this substance possesses central and peripheral analgesic actions in mice, with this effect being $108 \%$ more potent than that of morphine.

Fixed oils obtained from the body fat of reptiles have shown a predominance of unsaturated fatty acids when compared to saturated fatty acids (Ferreira et al. 2010; Cabral et al. 2013). Dias et al. (2013) verified that the body fat of Phrynops geoffroanus is composed of $84.63 \%$ and $13.38 \%$ unsaturated and saturated methyl esters, respectively. Among the constituents identified in the $P$. geoffroanus fixed oil, palmitoleic and oleic acids were present in greater amounts and accounted for $58.39 \%$ and $15.7 \%$ of the extract's composition, respectively. This species displayed antifungal modifying activity against $C$. albicans strains. For lizards used as a zootherapy, fat from Tupinambis merianae was evaluated for its anti-inflammatory activity (Ferreira et al. 2010), and it demonstrated a reduction in inflammation in mouse ear edema models; however, analyses of the antibacterial activity of $T$. merianae fat (Ferreira et al. 2009) and skin (Ferreira et al. 2018) did not identify antibacterial action. The fat from Tropidurus hispidus lizards also showed antibiotic modifying activity (Santos et al. 2015). Bioprospecting of reptile fat to determine the antibacterial and antibiotic activity modifying effects also showed that fat from Boa constrictor, Spilotes pullatus and Crotalus durissus snakes exhibited a synergistic effect when combined with aminoglycosides (Ferreira et al. 2009; Oliveira et al. 2014).

Oliveira et al. (2014) analyzed the chemical composition of the oil obtained from the body fat of the Spilotes pullatus snake and revealed the presence of 10 fatty acids that accounted for $94.97 \%$ of the extract's chemical composition. The authors observed a higher concentration of unsaturated fatty acids than saturated fatty acids (61.38\% and 33.59 , respectively), with the unsaturated fatty acids elaidic acid $(37.26 \%)$ and linoleic acid (17.28\%) and the saturated fatty acids palmitic acid (19.01\%) and stearic acid (10.58\%) predominating.

Extracts and decoctions of Tropidurus hispidus, Tropidurus semitaeniatus, Ameiva ameiva, Tupinambis merianae, Iguana, $B$. constrictor and $C$. durissus reptiles were also examined as potential antibacterial agents (Santos et al. 2012a, b; Ferreira et al. 2018.). However, modifying activity was only validated for $T$. hispidus, T. semitaeniatus and $A$. ameiva (Santos et al. 2012a, b). In anti-inflammatory activity validation studies using paw and ear edema models, skin decoctions from C. durissus, I. iguana, and $B$. constrictor reduced inflammation (Ferreira et al. 2014).

The Leptodactylus and Rhinella genera are among the Caatinga amphibians used in popular medicine. Cabral et al. (1926) investigated the chemical composition of fixed oils obtained from the body fat of two 
species belonging to the Leptodactylus genus, Leptodactylus macrosternum Miranda-Ribeiro (1926) and Leptodactylus vastus Adolf Lutz (1930) and observed that the oil obtained from $L$. macrosternum contained $40 \%$ saturated fatty acids and $60 \%$ unsaturated fatty acids while the oil obtained from L. vastus contained $58.33 \%$ saturated fatty acids and $41.67 \%$ unsaturated fatty acids. In the aforementioned study, both species possessed common constituents, including methyl myristate, methyl pentadeacanoate, methyl palmitoleate, methyl linoleate, methyl estereate and methyl 5,8,11,14eicosatetraenoate. The authors stated that the presence of large amounts of unsaturated fatty acids in the $L$. macrosternum and $L$. vastus fixed oils was unexpected and indicated that the animals' diets potentially influencing this result since essential fatty acids are not synthesized by animals.

In the study by Sousa et al. (2009), the authors identified and isolated a new neutral peptide rich in glycine/leucine called leptoglycine from Leptodactylus pentadactylus Laurenti skin secretions. The authors observed that this peptide displayed a significant antimicrobial effect and could inhibit the growth of different gram-negative bacteria, such as $P$. aeruginosa, $E$. coli and Citrobacter freundii. Limaverde et al. (2009) isolated the protein toxin leptoxin and investigated its toxicological properties in a study performed with $L$. pentadactylus skin secretions, observing that leptoxin promotes death in mice because of acute lung edema because of an increase in lung microvascular pressure arising from direct vasoconstriction induced by this substance.

Studies with species belonging to the Rhinella genus have identified the presence of different saturated fatty acids, including lauric acid, myristic acid, pentadecanoic acid, stearic acid, palmitic acid and heptadecanoic acid, and of unsaturated fatty acids, including arachidonic acid, linoleic acid, oleic acid and palmitolytic acid, in fixed oils obtained from the body fat of Rhinella jimi frogs (Stevaux 2002) (Sales et al. 2015). Moreover, the study by Sales et al. (2017) analyzed secretions obtained from the parotid glands of the aforementioned species and identified the presence of bufotenin, dehydro-bufotenin, marinobufagine, telocinobufagine, and bufaline. Similar constituents were also identified in venom extracted from Bufo schneideri Werner, namely, marinobufagine, telocinobufagine and bufaline (Freitas 2003).

Regarding wild mammals, Ferreira et al. (2018) evaluated the antibacterial activity of fat from Euphractus sexcinctus and spines from Coendou prehensilis, although the antibacterial action of its components was not validated. Fats from mammals and domestic fowl are also described as zootherapies used in the Caatinga biome for diseases affecting domestic animals and humans (Ferreira et al. 2012; Dias et al. 2018, Dias et al. 2019a, 2019b). In the study by Dias et al. (2019a), the antibacterial and antibiotic modifying action of fats from the mammals Bos taurus, Capra hircus, and Ovis aries domestic against bacteria of veterinary interest were analyzed, and these fats showed antibiotic modifying activity for terramycin, norfloxacin, amikacin, and amoxicillin. This same modifying activity was also found for fat from Sus scrofa domesticus (Dias et al. 2019b), Gallus gallus birds, and Meleagris gallopavo (Dias et al. 2018). For invertebrates, the modifying activity of aminoglycoside antibiotics associated with products derived from the termite Nasutitermes corniger was also observed (Coutinho et al. 2009; Coutinho et 
al. 2010).

\section{Perspectives and gaps}

Although hundreds of plants occurring in the Caatinga have been identified, studies on their secondary metabolites are still limited with respect to the isolation and identification of bioactive molecules. As listed above, a large proportion of the studies are only aimed at verifying the presence of metabolites and quantifying them. Because the Caatinga is a unique ecosystem, greater partnerships with universities and research centers can provide greater insights into the phytochemistry of species occurring in the Caatinga, especially the endemic species. This collaborative effort may be important to investigate a set of questions that require the interaction of different lines of research. For example, these investigations could assess what the perceived characteristics of the medicinal plants by people (smell, taste) would be more associated with their pharmacological potential. These studies will be interesting in the future as they may benefit bioprospecting by highlighting a set of important plant characteristics from local knowledge that may be essential in finding new candidates for disease treatment. In addition, future efforts could also be directed to verify if the pharmacological potential of plants varies in response to the marked climatic seasonality of the Caatinga (see, for example, Monteiro et al. 2006a) and/or to the diversity of climatic conditions present in the region.

The ethnopharmacological data on zootherapeutics enable the discovery of new drugs and may also serve as a guide for the rational and sustainable use of exploited species (Alves 2009; Ferreira et al. 2012). Research has shown that the animal species used for traditional medicine are threatened with extinction, and information on the biological activity of these resources may not be available (Alves and Rosa 2005, 2007c).

The treatment of human and animal diseases using animal derivatives constitute the basis of many traditional therapeutic systems and is considered relevant to science, thus necessitating a better understanding of the biological, social, cultural and economic aspects of these resources (Lev 2003; Alves and Albuquerque 2013).

Bioprospecting studies investigating the activities of fats from domestic animals that are also used as zootherapeutics were reviewed here (Dias et al. 2018, Dias et al. 2019a, 2019b). These studies have shown that fats from domestic species present the same ability to modulate antibiotic activity as the fats from wild species, which indicates that possible substitutes may be available for products from endangered species.

\section{ACKNOWLEDGMENTS}

We acknowledge the Brazilian National Council for Scientific and Technological Development (CNPq) for the research productivity grant awarded to UPA, RRNA, $\mathrm{HDC}$ and $\mathrm{ML}$; and the contribution of the INCT Ethnobiology, Bioprospecting and Nature Conservation, certified by CNPq, with financial support from FACEPE (Foundation for Support to Science and Technology of the State of Pernambuco -Grant number: APQ-0562-2.01/17).

\section{REFERENCES}

Adwan H, Murtaja A, Kadhim Al-Taee K, Pervaiz A, Hielscher T, Berger MR (2014) Riproximin's activity depends on gene expression and sensitizes PDAC cells to TRAIL. Cancer 
Biology \& Therapy 15:1185-1197. https://doi.org/ 10.4161/cbt.29503

Agra MF, Silva KN, Basílio IJLD, Freitas PF, Barbosa-Filho JM (2008) Survey of medicinal plants used in the region Northeast of Brazil. Revista Brasileira de Farmacognosia 18:472$508 . \quad$ https://doi.org/10.1590/S0102$695 \times 2008000300023$

Agra MF, Baracho GS, Nurit K, Basílio IJLD, Coelho VPM (2007) Medicinal and poisonous diversity of the flora of "Cariri Paraibano." Brazilian Journal of Pharmacognosy 111:383395. https://doi.org/10.1016/j.jep.2006.12.007

Aguiar Galvão W, Braz-Filho R, Canuto KM, Ribeiro PRV, Campos AR, Moreira ACOM, Silva SO, Filho FAM, Santos SAAR, Melo Júnior JMA, Gonçalves NGG, Fonseca SGC, Bandeira MAM (2018) Gastroprotective and antiinflammatory activities integrated to chemical composition of Myracrodruon urundeuva Allemão - A conservationist proposal for the species. Journal of Ethnopharmacology. 222:177-189. https://doi.org/10.1016/j.jep. 2018.04.024

Albuquerque UP (2006) Re-examining hypotheses concerning the use and knowledge of medicinal plants: a study in the Caatinga vegetation of NE Brazil. Journal of Ethnobiology and Ethnomedicine 2:30. https:// doi.org/10.1186/1746-4269-2-30

Albuquerque UP, Medeiros PM, Almeida ALS, Monteiro JM, Lins-Neto EMF, Melo JG, Santos JP (2007) Medicinal plants of the caatinga (semi-arid) vegetation of NE Brazil: a quantitative approach. Journal of Ethnopharmacology 114:325-354. https://doi.org/ 10.1016/j.jep.2007.08.017

Albuquerque UP, Medeiros PM, Ramos MA, Ferreira Júnior WS, Nascimento ALB, Torres Avilez WM, Melo JG (2014) Are ethnopharmacological surveys useful for the discovery and development of drugs from medicinal plants? Revista Brasileira de Farmacognosia 24:110-115. http://doi.org/ 10.1016/j.bjp.2014.04.003

Albuquerque UP, Oliveira RF (2007) Is the useimpact on native caatinga species in Brazil reduced by the high species richness of medicinal plants? Journal of Ethnopharmacology 113:156-170. https://doi.org/ 10.1016/j.jep.2007.05.025
Albuquerque UP, Araújo EL, Castro CC, Alves RRN (2017) People and natural resources in the Caatinga. In: Silva JMC, Leal IR, Tabarelli M. (eds) Caatinga: The largest tropical dry forest region in South America. Springer, Basel, Switzerland, pp. 303-333.

Alencar NL, Santoro FR, Albuquerque UP (2014) What is the role of exotic medicinal plants in local medical systems? A study from the perspective of utilitarian redundancy. Revista Brasileira de Farmacognosia 24:506-515. http:// doi.org/10.1016/j.bjp.2014.09.003

Alencar NL, Sousa Araújo TA, Amorim ELC, Albuquerque UP (2010) The inclusion and selection of medicinal plants in traditional pharmacopoeias-evidence in support of the diversification hypothesis. Economic Botany 64:68-79. https://doi.org/10.1007/s12231-0099104-5

Almeida CFCBR, Amorim ELC, Albuquerque UP (2011) Insights into the search for new drugs from traditional knowledge: An ethnobotanical and chemical-ecological perspective. Pharmaceutical Biology 49:864873.

10.3109/13880209.2010.551777

http://doi.org/

Almeida CFCBR, Lima e Silva TC, Amorim ELC, Maia MBS, Albuquerque UP (2005) Life strategy and chemical composition as predictors of the selection of medicinal plants from the Caatinga (Northeast Brazil). Journal of Arid Environments 62:127-142. http://doi.org/10.1016/ j.jaridenv.2004.09.020

Almeida J, Souza AV, Oliveira AP, Santos U, Souza M, Bispo L, Turatti ZC, Lopes N (2014a) Chemical composition of essential oils from Croton conduplicatus (Euphorbiaceae) in two different seasons. Journal of Essential Oil Bearing Plants 17:1137-1145. http://doi.org/ 10.1080/0972060X.2014.931254

Almeida JRGS, Araújo CS, Pessoa CO, Costa MP, Pacheco AGM (2014b) Atividade antioxidante, citotóxica e antimicrobiana de Annona vepretorum Mart. (Annonaceae). Revista Brasileira de Fruticultura 36:258-264. https://doi.org/10.1590/s0100-

\section{0}

Almeida L, Oshiro Júnior J, Silva M, Nóbrega $F$, Andrade J, Santos W, Ribeiro A, Conceição M, Veras G, Medeiros A (2019) Tablet of Ximenia americana L. Developed from Mucoadhesive Polymers for Future Use in Oral Treatment of Fungal Infections. Polymers 11:379. https:// doi.org/10.3390/polym11020379 
Almeida MLB, Freitas WES, Morais PLD, Sarmento JDA, Alves RE (2016) Bioactive compounds and antioxidant potential fruit of Ximenia americana L. Food Chemistry 192:1078-1082.

Almeida TS, Rocha JBT, Rodrigues FFG, Campos AR, Da Costa JGM (2013) Chemical composition, antibacterial and antibiotic modulatory effect of Croton campestris essential oils. Industrial Crops and Products 44:630-633.

Almeida VL, Silva CG, Silva AF, Campana PRV, Foubert K, Lopes JCD, Pieters L (2019) Aspidosperma species: A review of their chemistry and biological activities. Journal of Ethnopharmacology. 231:125-140. https:// doi.org/10.1016/j.jep.2018.10.039

Andrade FI, Purgato GA, Maia FT, Siqueira RP, Lima S, Diaz G, Diaz MA (2015) Chemical constituents and an alternative medicinal veterinary Herbal soap made from Senna macranthera. Evidence-Based Complementary and Alternative Medicine https://doi.org/ 10.1155/2015/217598

Alves DR, Morais SM, Tomiotto-Pellissier F, Miranda-Sapla MM, Vasconcelos FR, Silva ING, Sousa HA, Assolini JP, Conchon-Costa I, Pavanelli WR, Freire FCO (2017) Flavonoid Composition and Biological Activities of Ethanol Extracts of Caryocar coriaceum Wittm., a native plant from Caatinga Biome. Evidence-Based Complementary and Alternative Medicine http://doi.org/10.1155/2017/6834218

Alves GA, Vinholis AHC, Casemiro LA, Furtado NAJC, Silva MLA, Cunha WR, Martins CHG (2008) Estudo comparativo de técnicas de screening para avaliação da atividade antibacteriana de extratos brutos de espécies vegetais e de substâncias puras. Quimica Nova 31:1224-1229.

Alves RRN, Pereira-Filho GA (2007) Commercialization and use of snakes on North and Northeastern Brazil: implications for conservation and management. Biodiversity and Conservation 16:969-985.

Alves RRN, Rosa IL (2005) Why study the use of animal products in traditional medicines? Journal of Ethnobiology and Ethnomedicine 1:15.

Alves RRN, Rosa IL (2006) From cnidarians to mammals: The use of animals as remedies in fishing communities in NE Brazil. Journal of Ethnopharmacology 107:259-276.
Alves RRN, Rosa IL, Santana GG (2007) The role of animal-derived remedies as complementary medicine in Brazil. BioScience 57:949-955.

Alves RRN, Rosa IL (2007a) Biodiversity, traditional medicine and public health: where do they meet? Journal of Ethnobiology and Ethnomedicine 3:1-9.

Alves RRN, Rosa IL (2007b) Zootherapeutic practices among fishing communities in North and Northeast Brazil: A comparison. Journal of Ethnopharmacology 111:82-103.

Alves RRN, Rosa IL (2007c) Zootherapy goes to town: The use of animal-based remedies in urban areas of NE and $\mathbf{N}$ Brazil. Journal of Ethnopharmacology 113:541-555.

Alves RRN, Lima HN, Tavares MC, Souto WMS, Barboza RRD, Vasconcellos A (2008a) Animalbased remedies as complementary medicines in Santa Cruz do Capibaribe, Brazil. BMC Complementary and Alternative Medicine 8:1-9.

Alves RRN, Vieira WLS, Santana GG (2008b) Reptiles used in traditional folk medicine: conservation implications. Biodiversity and Conservation 17:2037-2049.

Alves RRN (2009) Fauna used in popular medicine in Northeast Brazil. Journal of Ethnobiology and Ethnomedicine 5:1-11.

Alves RRN, Mendonça LET, Confessor MVA, Vieira WLS, Lopez LCS (2009a) Hunting strategies used in the semi-arid region of northeastern Brazil. Journal of Ethnobiology and Ethnomedicine 5(12):1-50.

Alves RRN, Oliveira MGG, Barboza RRD, Singh R, Lopez LCS (2009b) Medicinal Animals as therapeutic alternative in a semi-arid region of Northeastern Brazil. Forsch Komplementmed/Research in Complementary Medicine 16:305-312.

Alves RRN, Oliveira MGG, Barboza RRD, Lopez LCS (2010) An ethnozoological survey of medicinal animals commercialized in the markets of Campina Grande, NE Brazil. Human Ecology Review 17(1):11-17.

Alves RRN, Alves HN (2011) The faunal drugstore: Animal-based remedies used in traditional medicines in Latin America. Journal of Ethnobiology and Ethnomedicine 7:143. 
Alves RRN, Pereira Filho GA, Silva Vieira K, Souto WMS, Mendonças LET, Montenegro PFGP, Almeida WO, Vieira WLS (2012) A zoological catalogue of hunted reptiles in the semiarid region of Brazil. Journal of Ethnobiology and Ethnomedicine 8(1):27.

Alves RRN, Albuquerque UP (2013) Animals as a Source of Drugs: Bioprospecting and Biodiversity Conservation. In: Alves RRN, Rosa IL (eds) Animals in Traditional Folk Medicine. Springer, New York, pp. 67-89.

Alves RRN, Feijó A, Barboza RRD, Souto WMS, Fernandes-Ferreira $\mathrm{H}$, Cordeiro-Estrela $P$, Langguth A (2016a) Game mammals of the Caatinga biome. Ethnobiology and Conservation 5:1-51.

Alves RRN, Melo MF, Ferreira FS, Trovão DMBM, Dias TLP, Oliveira JV, Lucena RFP, Barboza RRD (2016b) Healing with animals in a semiarid northeastern area of Brazil. Environment, Development and Sustainability 18(6):1733-1747.

Alviano WS, Alviano DS, Diniz CG, Alviano CS, Farias LM, Carvalho MA, Souza MG, Bolognese AM (2008) In vitro antioxidant potential of medicinal plant extracts and their activities against oral bacteria based on Brazilian folk medicine. Archives of Oral Biology 53: 545-552.

Andrade JC, Silva ARP, Santos ATL, Freitas MA, Carneiro JNP, Gonçalo MIP, de Souza A, Freitas TS, Ribeiro PRV, Brito ES, Morais-Braga MFB, Coutinho HDM (2019) UPLC-MS-ESI-QTOF characterization and evaluation of the antibacterial and modulatory antibiotic activity of Ziziphus joazeiro Mart. aqueous extracts. South African Journal of Botany 123: 105-112.

https://doi.org/10.1016/j.sajb.

2019.02.001

Anjos QQA, Silva SLC, Silva DC, Gualberto SA, Santos FR, Carvalho MG, Sousa DL (2018) Chemical composition of the essential oil of the Croton tetradenius (Euphorbiaceae) aerial part and bioactivity on Aedes Aegypti (diptera: Culicidae) in relation to different collection periods. Periodico Tche Quimica 15:364-379.

Ankli A, Sticher O, Heinrich M (1999) Yucatec Maya medicinal plants versus nonmedicinal plants: indigenous characterization and selection. Human Ecology 27:557-580. https:// doi.org/10.1023/A:1018791927215
Aragao TP, Prazeres LDKT, Brito SA, Neto PJR, Rolim LA, Almeida JRGS, Caldas GFR, Wanderley AG (2018) Contribution of Secondary Metabolites to the Gastroprotective Effect of Aqueous Extract of Ximenia americana L. (Olacaceae) Stem Bark in Rats. Molecules 23:112. https://doi.org/ 10.3390/molecules23010112

Araújo CS, Oliveira AP, Lima RN, Alves PB, Diniz TC, Almeida JRGS (2015a) Chemical constituents and antioxidant activity of the essential oil from leaves of Annona vepretorum Mart. (Annonaceae). Pharmacognosy 11:615-618. https://doi.org/ 10.4103/0973-1296.160462

Araújo TAS, Almeida e Castro VTN, Solon LGS, Silva GA, Almeida MG, Costa JGM, Amorim ELC, Albuquerque UP (2015b) Does rainfall affect the antioxidant capacity and production of phenolic compounds of an important medicinal species? Industrial Crops and Products 76:550-556. http://doi.org/10.1016/ j.indcrop.2015.07.008

Araújo HFP, Silva JMC (2017) The avifauna of the Caatinga: Biogeography, ecology, and conservation. In: Silva JMC, Leal IR, Tabarelli $M$ (eds) Caatinga: The largest tropical dry forest region in South America. Springer, Basel, Switzerland, pp. 181-210.

Araújo DP, Nogueira PCN, Santos ADC, Costa RO, Lucena JD, Gadelha-Filho CVJ, Lima FAV, Neves KRT, Leal LKAM, Silveira ER, Viana GSB (2018) Aspidosperma pyrifolium Mart: neuroprotective, antioxidant and antiinflammatory effects in a Parkinson's disease model in rats. Journal of Pharmacy and Pharmacology 70:787-796. https://doi.org/ 10.1111/jphp.12866

Araújo JX, Antheaume C, Trindade RCP, Schmitt M, Bourguignon JJ, Sant'Ana AEG (2007) Isolation and characterisation of the monoterpenoid indole alkaloids of Aspidosperma pyrifolium. Phytochemistry Reviews 6:183-188. https://doi.org/10.1007/ s11101-006-9044-y

Araújo TAS, Alencar NL, Amorim ELC, Albuquerque UP (2008) A new approach to study medicinal plants with tannins and flavonoids contents from the local knowledge. Journal of Ethnopharmacology 120:72-80. https://doi.org/10.1016/j.jep. 
Araújo TAS, Almeida e Castro VTN, Amorim ELC, Albuquerque UP (2012) Habitat influence on antioxidant activity and tannin concentrations of Spondias tuberosa. Pharmaceutical Biology 50:754-759. https:// doi.org/10.3109/13880209.2011.630673

Areche C, Schmeda-Hirschmann G, Theoduloz C, Rodríguez JA (2009) Gastroprotective effect and cytotoxicity of abietane diterpenes from the Chilean Lamiaceae Sphacele chamaedryoides (Balbis) Briq. Journal of Pharmacy and Pharmacology 61:1689-1697. https://doi.org/10.1211/jpp/61.12.0015

Asres K, Bucar F, Kartnig T, Witvrouw M, Pannecouque C, De Clercq E (2001) Antiviral activity against human immunodeficiency virus type 1 (HIV-1) and type 2 (HIV-2) of ethnobotanically selected Ethiopian medicinal plants. Phytotherapy Research 15:6269.

Aye MM, Aung HT, Sein MM, Armijos C (2019) A Review on the Phytochemistry, Medicinal Properties and Pharmacological Activities of 15 Selected Myanmar Medicinal Plants. Molecules 24:293. https://doi.org/10.3390/ molecules24020293

Baldissera MD, de Freitas Souza C, Mourão RHV, da Silva LVF, Monteiro SG (2017) Trypanocidal action of Lippia alba and Lippia origanoides essential oils against Trypanosoma evansi in vitro and in vivo used mice as experimental model. Journal of Parasitic Diseases 41:345-351. https://doi.org/ 10.1007/s12639-016-0800-7

Barberino RS, Barros VRP, Menezes VG, Santos LP, Araújo VR, Queiroz MAA, Almeida JRGS, Palheta RC, Matos MHT (2016) Amburana cearensis leaf extract maintains survival and promotes in vitro development of ovine secondary follicles. Zygote 24:277-285. https:// doi.org/10.1017/S0967199415000179

Barbosa HM, Amaral D, Nascimento JN, Machado DC, Araújo TAS, Albuquerque UP, Almeida JRGS, Rolim LA, Lopes NP, Gomes DA, Lira EC (2018) Spondias tuberosa inner bark extract exert antidiabetic effects in streptozotocin-induced diabetic rats. Journal of Ethnopharmacology 227:248-257. https:// doi.org/10.1016/j.jep.2018.08.038

Barbosa-Filho JMB, Trigueiro JA, Cheriyan UO, Bhattacharyya J (1985) Constituents of the stem-bark of Zizyphus joazeiro. Journal of Natural Products 48:152-153. https://doi.org/ 10.1021/np50037a039
Barbosa HM, Nascimento JN, Araújo TAS, Duarte FS, Albuquerque UP, Vieira JRC, Santana ERB, Yara R, Lima CSA, Gomes DA, Lira EC (2016) Acute Toxicity and Cytotoxicity effect of ethanolic extract of Spondias tuberosa Arruda bark: hematological, biochemical and histopathological evaluation. Anais da Academia Brasileira de Ciências 88:1993-2004. https://doi.org/ 10.1590/0001-3765201620160041

Barbosa MO, Coutinho DJG, Santos J, Cordeiro RP, Muniz LR, Alves RC, Bessa CMAS, da Silva M, Oliveira MBPP, Oliveira AFM (2019) Fatty acids, tocopherols and tocotrienols composition in seed oils of Brazilian species of Sapindaceae and Meliaceae. Journal of Food Science and Technology 1-7. http://doi.org/ 10.1007/s13197-019-03800-y

Barbosa PBBM, Oliveira JM, Chagas JM, Rabêlo LMA, Medeiros GF, Giodani RB, Silva EA, Uchôa AF, Ximenes MFFM (2014) Evaluation of seed extracts from plants found in the Caatinga biome for the control of Aedes aegypti. Parasitology Research 113:3565-3580. https:// doi.org/10.1007/s00436-014-4022-6

Barboza RRD, Lopes SF, Souto WMS, Fernandes-Ferreira H, Alves RRN (2016) The role of game mammals as bushmeat in the Caatinga, northeast Brazil. Ecology and Society 21(2):1-11.

Barros TFS, Arriel NHC, Queiroz MF, Fernandes PD, Mendonça S, Ribeiro JAA, Medeiros EP (2015) Fatty acid profiles of species of Jatropha curcas L., Jatropha mollissima (Pohl) Baill. and Jatropha gossypiifolia L. Industrial Crops and Products 73:106-108. http:// doi.org/10.1016/j.indcrop.2015.04.00

Beserra AMSS, Vilegas W, Tangerina MMP, Ascêncio SD, Soares IM, Pavana E, Damazo AS, Ribeiro RV, Martins DTO (2018) Chemical characterization and toxicity assessment in vitro and in vivo of the hydroethanolic extract of Terminalia argentea Mart. leaves. Journal of Ethnopharmacology 227:56-68. http://doi.org/ 10.1016/j.jep.2018.08.025

Bezerra DMM, Araújo HFP, Alves ÂGC, Alves RRN (2013) Birds and people in semiarid northeastern Brazil: symbolic and medicinal relationships. Journal of Ethnobiology and Ethnomedicine 9:3. 
Bitu VCN, Bitu VCN, Matias EFF, Lima WP, Portelo AC, Coutinho HDM, Menezes IRA (2015) Ethnopharmacological study of plants sold for therapeutic purposes in public markets in Northeast Brazil. Journal of Ethnopharmacology 172:265-72. 2015.06.022

Blum D, Torch S, Lambeng N, Nissou M, Benabid AL, Sadoul R, Verna JM (2001) Molecular pathways involved in the neurotoxicity of 6-OHDA, dopamine and MPTP: contribution to the apoptotic theory in Parkinson's disease. Progress in Neurobiology 65:135-172.

Bomfim LM, Menezes LRA, Rodrigues ACBC, Dias RB, Gurgel Rocha CA, Soares MBP, Neto AFS, Nascimento MP, Campos AF, Silva LCRC, Costa EV, Bezerra DP (2016) Antitumour Activity of the Microencapsulation of Annona vepretorum Essential Oil. Basic \& Clinical Pharmacology \& Toxicology 118:208-213. https:// doi.org/10.1111/bcpt.12488

Botelho MA, Rao VS, Montenegro D, Bandeira MAM, Fonseca SGC, Nogueira NAP, Ribeiro RA, Brito GAC (2008) Effects of a herbal gel containing carvacrol and chalcones on alveolar bone resorption in rats on experimental periodontitis. Phytotherapy Research 22:442-449. https://doi.org/10.1002/ptr. 2325

Brandão GHA, Rigo G, Roque AA, Souza ACD, Scopel M, Nascimento CAO, Tasca T, Pereira CG, Giordani GB (2017) Extraction of bioactive alkaloids from Melocactus zehntineri using supercritical fluid. Journal of Supercritical Fluids 129:28-35. http://doi.org/10.1016/j.supflu. 2016.12.012

Brito FCR, Moura LFWG, Morais VD, Mendes ALRF, Moreira MR, Sousa VSS, Lustosa IBS, Sampaio RMM, Santos AAQA, Guedes MIF (2018) Ethno-pharmacological studies of Brazilian Caatinga plants: a review. International Journal of Development Research 8:23763-23766.

Brito FN, Vendramin FS, Lopes CTDA, Costa MPR, Ohashi OM, Maia JGS, Ferreira LM, Silva RJK, Miranda MDS (2018) Proliferation of human adipose tissue-derived stem cells stimulated by oil rich in thymol of Lippia origanoides. Acta Cirúrgica Brasileira 33(5):431$438 . \quad$ https://doi.org/10.1590/s0102865020180050000005
Brito SMO, Coutinho HDM, Talvani A, Coronel C, Barbosa AGR, Vega C, Figueredo FG, Tintino SR, Lima LF, Boligon AA, Athayde ML, Menezes IRA (2015) Analysis of bioactivities and chemical composition of Ziziphus joazeiro Mart. using HPLC-DAD. Food Chemistry 186:185-191. https://doi.org/10.1016/j.foodchem. 2014.10.031

Brito-Filho SG, Maciel JKS, Teles YCF, Fernandes MMMS, Chaves OS, Ferreira MDL, Fernandes PD, Félix LP, Cirino ICS, SiqueiraJúnior JP, Braz-Filho R, de Souza MFV (2017) Phytochemical study of Pilosocereus pachycladus and antibiotic-resistance modifying activity of syringaldehyde. Brazilian Journal of Pharmacognosy 27:453-458. http:// doi.org/10.1016/j.bjp.2017.06.001

Buckingham J, Munasinghe VRN (2015) Dictionary of Flavonoids with CD-ROM. 1 ed. CRC Press, Boca Raton, Florida, pp. 1199. https://doi.org/10.1201/b18170

Cabral MES, Dias DQ, Sales DL, Oliveira OP, Araújo-Filho JA, Teles DA, Sousa JGG, Coutinho HDM, Costa JGM, Kerntopf MR, Alves RRN, Almeida WO (2013) Evaluations of the antimicrobial activities and chemical compositions of body fat from the amphibians Leptodactylus macrosternum Miranda-Ribeiro (1926) and Leptodactylus vastus Adolf Lutz (1930) in the Northeastern Brazil. BMC Complementary and Alternative Medicine 2013:1-7.

Calou I, Bandeira MA, Aguiar-Galvão W, Cerqueira G, Siqueira R, Neves KR, Brito GA, Viana G (2014) Neuroprotective Properties of a Standardized Extract from Myracrodruon urundeuva Fr. All. (Aroeira-Do-Sertão), as Evaluated by a Parkinson's Disease Model in Rats. Parkinson's Disease 2014:1-11. https:// doi.org/10.1155/2014/519615

Campos VA, Perina FJ, Alves E, Sartorelli J, Moura AM, Oliveira DF (2014) Anadenanthera colubrina (Vell.) Brenan produces steroidal substances that are active against Alternaria alternata (Fr.) Keissler and that may bind to oxysterol-binding proteins. Pest Management Science 70:1815-1822. https://doi.org/10.1002/ ps.3722 
Carvalho KS, Silva SL., de Souza IA, Gualberto SA, da Cruz RCD, dos Santos FR, de Carvalho MG (2016) Toxicological evaluation of essential oil from the leaves of Croton tetradenius (Euphorbiaceae) on Aedes aegypti and Mus musculus. Parasitology Research 115:3441-3448. http://doi.org/10.1007/ s00436-016-5106-2

Casagrande DG (2000) Human taste and cognition in Tzeltal Maya medicinal plant use. Journal of Ecological Anthropology 4:57-69. http://doi.org/10.5038/2162-4593.4.1.3

Carmignotto AP, Astúa D (2017) Mammals of the Caatinga: Diversity, ecology, biogeography, and conservation. In: Silva JMC, Leal IR, Tabarelli M (eds) Caatinga: The largest tropical dry forest region in South America. Springer, Basel, Switzerland, pp. 211255.

Ceravolo IP, Zani CL, Figueiredo FJB, Kohlhoff M, Santana AEG, Krettli AU (2018) Aspidosperma pyrifolium, a medicinal plant from the Brazilian Caatinga, displays a high antiplasmodial activity and low cytotoxicity. Malaria Journal 17:436. http://doi.org/10.1186/ s12936-018-2568-y

Cordeiro BMPC, Santos NDL, Ferreira MRA, Araújo LCC, Carvalho Júnior AR, Santos ADC, Oliveira AP, Silva AG, Falcão EPS, Correia MTS, Almeida JRGS, Silva LCN, Soares LAL, Napoleão TH, Silva MV, Paiva PMG (2018) Hexane extract from Spondias tuberosa (Anacardiaceae) leaves has antioxidant activity and is an anti-Candida agent by causing mitochondrial and lysosomal damages. BMC Complementary and Alternative Medicine 18:284. http://doi.org/10.1186/s12906018-2350-2

Costa EV, Dutra LM, Nogueira PCL, Moraes VRS, Salvador MJ, Ribeiro LHG, Gadelha FR (2012) Essential oil from the leaves of Annona vepretorum: chemical composition and bioactivity. Natural Product Communications 7(2): 265-266

Costa Filho LO, Moura Silva MH, Almeida-Cortez JS, Silva, SI, Oliveira AFM (2012) Foliar cuticular n-alkane of some Croton species from Brazilian semiarid vegetation. Biochemical Systematics and Ecology 41:13-15. https://doi.org/10.1016/j.bse.2011.11.005
Costa-Lotufo LV, Jimenez PC, Wilke DV, Leal LKAM, Cunha GMA, Silveira ER, Canuto KM, Viana GSB, Moraes MEA, Moraes MO, Pessoa C (2003) Antiproliferative Effects of Several Compounds Isolated from Amburana cearensis A. C. Smith. Zeitschrift für Naturforschung. Section C, A European Journal of Biosciences 58:675-680.

Costa-Neto EM (1999) Healing with animals in Feira de Santana City, Bahia, Brazil. Journal of Ethnopharmacology 65:225-230.

Costa-Neto EM, Alves RRN (2010) Estado da arte da zooterapia popular no Brasil. In: Costa-Neto EM, Alves RRN (eds) Zooterapia: os animais na medicina popular brasileira. Nupeea, Recife, Brazil.

Coutinho DJG, Barbosa MO, Silva RM, Silva SI, Oliveira AFM (2015) Fatty-Acid Composition of Seeds and Chemotaxonomic Evaluation of Sixteen Sapindaceae Species. Chemistry and Biodiversity 12:1271-1280. http://doi.org/ 10.1002/cbdv.201400325

Coutinho DJG, Barbosa MO, Souza RJC, Silva AS, Silva SI, Oliveira AFM (2016) Biodiesel potential of the seed oils from some Brazilian native Euphorbiaceae species. Renewable Energy 91:275-281. http://doi.org/10.1016/ j.renene.2016.01.064

Coutinho HDM, Almeida Filho GG, Pessoa HFL, Gadelha CA (2010) Natural products from the termite Nasutitermes corniger lowers aminoglicoside minimum inhibitory concentrations. Pharmacognosy 6:1-4.

Coutinho HDM, Vasconcellos A, Alves RRN, Almeida Filho GG, Lima MA (2009) Termite usage associated with antibiotic therapy: Enhancement of aminoglycoside antibiotic activity by natural products of Nasutitermes corniger (Motschulsky, 1855). BMC Complementary and Alternative Medicine 9:3-5. https://doi.org/10.1186/1472-6882-9-35

Craveiro AA, Matos FJA, Serur L (1983) Alkaloids of Aspidosperma pyrifolium. Phytochemistry 22:1526-1528. https://doiorg.ez16.periodicos.capes.gov.br/10.1016/ s0031-9422(00)84061-3

Crivelaro de Menezes TE, Delbem ACB, Brighenti FL, Okamoto AC, Gaetti-Jardim E (2010) Protective efficacy of Psidium cattleianum and Myracrodruon urundeuva aqueous extracts against caries development in rats. Pharmaceutical Biology 48:300-305. https://doi.org/10.3109/13880200903122202 
Cruz MCS, Santos PO, Barbosa AM, Melo DLFM, Alviano CS, Antoniolli AR, Alviano DS, Trindade RC (2007) Antifungal activity of Brazilian medicinal plants involved in popular treatment of mycoses. Journal of Ethnopharmacology 111:409-412.

da Costa Cordeiro BMP, Santos NDL, Ferreira MRA, Araújo LCC, Júnior ARC, Santos ADC, Oliveira AP, Silva AG, Falcão EPS, Correia MTS, Almeida JRGS, Silva LCN, Soares LAL, Napoleão TH, Silva MV, Paiva PMG (2018) Hexane extract from Spondias tuberosa (Anacardiaceae) leaves has antioxidant activity and is an anti-Candida agent by causing mitochondrial and lysosomal damages. BMC Complementary and Alternative Medicine 18(1):284. https://doi.org/10.1186/ s12906-018-2350-2

Dantas M, de Oliveira F, Bandeira S, Batista J, Silva C, Alves P, Antoniolli A, Marchioro M (2004) Central nervous system effects of the crude extract of Erythrina velutina on rodents. Journal of Ethnopharmacology 94:129-133. https://doi.org/10.1016/j.jep.2004.05.007

de Araújo Gomes LM, De Andrade TMD, Silva JC, de Lima JT, Quintans-Júnior LJ, Da Silva Almeida JRG (2014) Phytochemical screening and anti-inflammatory activity of Cnidoscolus quercifolius (Euphorbiaceae) in mice. Pharmacognosy Research 6:345-349. http:// doi.org/10.4103/0974-8490.138290

de Oliveira LMB, Bevilaqua CML, Macedo ITF, Morais SM, Machado LKA, Campello CC, Mesquita MA (2011) Effects of Myracrodruon urundeuva extracts on egg hatching and larval ensheathment of Haemonchus contortus. Parasitology Research 109:893898. https://doi.org/10.1007/s00436-011-2331-6

Diallo D, Sogn C, Samaké FB, Paulsen BS, Michaelsen TE, Keita A (2002) Wound Healing Plants in Mali, the Bamako Region. An Ethnobotanical Survey and Complement Fixation of Water Extracts from Selected Plants. Pharmaceutical Biology 40:117-128. https://doi.org/10.1076/phbi.40.2.117.5846

Dias DQ, Cabral MES, Sales DL, Oliveira OP, Araújo-Filho JA, Teles DA, Sousa JGG, Coutinho HDM, Costa JGM, Kerntopf MR, Alves RRN, Almeida WO (2013) Chemical composition and validation of the ethnopharmacological reported antimicrobial activity of the body fat of Phrynops geoffroanus used in traditional medicine. Evidence-Based Complementary and Alternative Medicine 2013:1-4. https://doi.org/ $10.1155 / 2013 / 715040$
Dias DQ, Sales DL, Andrade JC, Silva ANP, Tintino SR, Oliveira-Tintino DM, Delmondes GA, Barbosa MO, Coutinho HDM, Ferreira FS, Rocha MFG, Navarro DMAF, Rocha SKL, Costa JGM, Alves RRN, Almeida WO (2019a) Antibacterial and antibiotic modifying evaluation of ruminants' body fat used as zootherapeutics in ethnoveterinary practices in Northeast Brazil. Journal of Ethnopharmacology 233:87-93.

Dias DQ, Sales DL, Andrade JC, Silva ANP, Tintino SR, Oliveira-Tintino DM, Delmondes GA, Barbosa MO, Coutinho HDM, Ferreira FS, Rocha MFG, Navarro DMAF, Rocha SKL, Costa JGM, Alves RRN, Almeida WO (2019b) GC-MS analysis of the fixed oil from Sus scrofa domesticus Linneaus (1758) and antimicrobial activity against bacteria with veterinary interest. Chemistry and Physics of Lipids 219:23-27.

Dias DQ, Sales DL, Andrade JC, Silva ANP, Tintino SR, Oliveira-Tintino DM, Delmondes GA, Rocha MFG, Costa JGM, Alves RRN, Ferreira FS, Coutinho HDM, Alves RRN, Almeida WO (2018) Body fat modulated activity of Gallus gallus domesticus Linnaeus (1758) and Meleagris gallopavo Linnaeus (1758) in association with antibiotics against bacteria of veterinary interest. Microbial Pathogenesis 124:163-169.

Dias KCF, Almeida JC, Vasconcelos LC, Patrocínio MLV, Barbosa TM, Ximenes NC, Leitão AP de A, Louchard BO, Pimenta ATÁ, Pinto $F$ das CL, Leal LKAM, Honório Júnior JER, Vasconcelos SMM (2019) Standardized extract of Erythrina velutina Willd. attenuates schizophrenia-Like behaviours and oxidative parameters in experimental animal models. Journal of Pharmacy and Pharmacology 71:379_ 389. https://doi.org/10.1111/jphp.13039

Diaz MAN, Rossi CC, Mendonça VR, Silva DM, Ribon AOB, Aguilar AP, Muñoz GD (2010) Screening of medicinal plants for antibacterial activities on Staphylococcus aureus strains isolated from bovine mastitis. Revista Brasileira de Farmacognosia 20: 724728.

Diniz T, Araújo C, Cabral Silva J, Oliveira Júnior R, Raquel S, Quintans-Júnior L, Pereira Nunes X, Almeida JR (2013) Phytochemical screening and central nervous system effects of ethanolic extract of Annona vepretorum (Annonaceae) in mice. Journal of Medicinal Plants Research 7: 2729-2735. 
Diniz TC, de Oliveira Júnior RG, Medeiros MAMB, Gama e Silva M, Teles RBA, Menezes MB (2019) Anticonvulsant, sedative, anxiolytic and antidepressant activities of the essential oil of Annona vepretorum in mice: Involvement of GABAergic and serotonergic systems. Biomedicine and Pharmacotherapy 111:1074-1087. http://doi.org/10.1016/j.biopha. 2018.12.114

Dourado RCM, Silveira ER (2005) Preliminary investigation on the volatile constituents of Croton sonderianus Muell. Arg.: Habitat, plant part and harvest time variation. Journal of Essential Oil Research 17:36-40. http://doi.org/ 10.1080/10412905.2005.9698823

Dragos D, Gilca M (2018) Taste of phytocompounds: a better predictor for ethnopharmacological activities of medicinal plants than the phytochemical class? Journal of Ethnopharmacology 28:129-146. http://doi.org/ 10.1016/j.jep.2018.03.034

Dunn F (1976) Traditional Asian medicine and cosmopolitan medicine as adaptive systems. In: Leslie C (ed) Asian medical systems: a comparative study. University California Press, Oakland, California, pp. 133-158.

Dutra LM, Bomfim LM, Rocha SLA, Nepel A, Soares MBP, Barison A, Costa EV, Bezerra DP (2014) ent-Kaurane diterpenes from the stem bark of Annona vepretorum (Annonaceae) and cytotoxic evaluation. Bioorganic \& Medicinal Chemistry Letters 24:3315-3320. https://doi.org/10.1016/j.bmcl.2014.06.005

Feltrin C, Brambila PF, Simões CMO (2019) Development of Caco-2 cells-based gene reporter assays and evaluation of herb-drug interactions involving CYP3A4 and CYP2D6 gene expression. Chemico-Biological Interactions 25:79-89. http://doi.org/10.1016/j.cbi. 2019.01.030

Fernandes-Ferreira H, Alves RRN (2017) The researches on the hunting in Brazil: a brief overview. Ethnobiology and Conservation 6:1-6.

Ferreira Júnior WS, Ladio AH, Albuquerque UP (2011) Resilience and adaptation in the use of medicinal plants with suspected antiinflammatory activity in the Brazilian Northeast. Journal of Ethnopharmacology 138:238-252. http://doi.org/10.1016/j.jep. 2011.09.018
Ferreira Júnior WS, Silva TG, Menezes IRA, Albuquerque UP (2016) The role of local disease perception in the selection of medicinal plants: a study of the structure of local medical systems. Journal of Ethnopharmacology 181:146-157. http://doi.org/ 10.1016/j.jep.2016.01.038

Ferreira FS, Brito S, Ribeiro S, Almeida W, Alves RRN (2009) Zootherapeutics utilized by residents of the community Poco Dantas, Crato-CE, Brazil. Journal of Ethnobiology and Ethnomedicine 5(1):21.

Ferreira FS, Albuquerque UP, Coutinho HDM, Almeida WO, Alves RRN (2012) The trade in medicinal animals in Northeastern Brazil. Evidence-based Complementary and Alternative Medicine 2012:1-20. https://doi.org/ $10.1155 / 2012 / 126938$

Ferreira FS, Brito SV, Costa JGM, Alves RRN, Coutinho HDM, Almeida WO (2009) Is the body fat of the lizard Tupinambis merianae effective against bacterial infections? Journal of Ethnopharmacology 126:233-237.

Ferreira FS, Brito SV, Coutinho HDM, Souza EP, Almeida WO, Alves RRN (2018) Vertebrates as a Bactericidal Agent. EcoHealth 15(3):619626.

Ferreira FS, Brito SV, Sales DL, Alencar IR, Coutinho HDM, Souza EP, Almeida WO, Alves RRN (2014) Anti-inflammatory potential of zootherapeutics derived from animals used in Brazilian traditional medicine. Pharmaceutical Biology 52:1-8.

Ferreira FS, Brito SV, Saraiva RA, Araruna MKA, Menezes IRA, Costa JGM, Coutinho HDM, Almeida WO, Alves RRN (2010) Topical antiinflammatory activity of body fat from the lizard Tupinambis merianae. Journal of Ethnopharmacology 130:514-520.

Formagio ASN, Vieira MC, Volobuff CRF, Silva MS, Matos Al, Cardoso CAL, Foglio MA, Carvalho JE, Formagio ASN, Vieira MC, Volobuff CRF, Silva MS, Matos AI, Cardoso CAL, Foglio MA, Carvalho JE (2015) In vitro biological screening of the anticholinesterase and antiproliferative activities of medicinal plants belonging to Annonaceae. Brazilian Journal of Medical and Biological Research 48:308-315. https://doi.org/10.1590/1414-431x20144127 
Freitas CIA (2003) Estudo sobre a atividade antimicrobiana de substâncias extraídas e purificadas de secreções da pele de anfíbios. Programa de Pós-graduação em Farmacologia (PhD Thesis). Universidade Federal do Ceará, Fortaleza-CE, Brazil, 179 p.

Garda AA, Stein MG, Machado RB, Lion MB, Juncá FA, Napoli MF (2017) Ecology, biogeography, and conservation of Amphibians of the Caatinga. In: Silva JMC, Leal IR, Tabarelli M (eds) Caatinga: The largest tropical dry forest region in South America. Springer, Basel, Switzerland, pp. 133-150.

Geck MS, Cabras S, Casu L, Reyes García AJ, Leonti M (2017) The taste of heat: How humoral qualities act as a cultural filter for chemosensory properties guiding herbal medicine. Journal of Ethnopharmacology 198: 499-515.

2017.01.027

http://doi.org/10.1016/j.jep.

Gilbert B, Ferreira JM, Owellen RJ, Swanholm CE, Budzikiewicz H, Durham LJ, Djerassi C (1962) Mass spectrometry in structural and stereochemical problems pyrifoline and refractidine. Tetrahedron Letters 3:59-67. https://doi.org/10.1016/S0040-4039(00)70487-4

Gomes NF (2007) Estudo de um fator antinociceptivo de ação periférica extraído do veneno da serpente Crotalus durissus collilineatus. Programa de Pós-graduação em Ciências Fisiológicas (Master Science Dissertation), Universidade Estadual do Ceará, Fortaleza-CE, Brazil, 125p.

Gomes TB, Bandeira FPSDF (2012) The use and diversity of medicinal plants in a quilombola community in Raso da Catarina, Bahia. Acta Botanica Brasilica 26:796-809. http:// doi.org/10.1590/S0102-33062012000400009

Gouveia BB, Macedo TJS, Santos JMS, Barberino RS, Menezes VG, Müller MC, Almeida JRGS, Figueiredo JR, Matos MHT (2016) Supplemented base medium containing Amburana cearensis associated with FSH improves in vitro development of isolated goat preantral follicles. Theriogenology 86, 1275-1284. https://doi.org/10.1016/

j.theriogenology.2016.04.068

Grønhaug TE, Glæserud S, Skogsrud M, Ballo N, Bah S, Diallo D, Paulsen BS (2008) Ethnopharmacological survey of six medicinal plants from Mali, West-Africa. Journal of Ethnobiology and Ethnomedicine 4:26. https://doi.org/10.1186/1746-4269-4-26
Gunstone FD (1996) Fatty Acid and Lipid Chemistry. 1 ed. Blackie Academic \& Professional, New York, USA.

Hernandes C, Pina ES, Taleb-Contini SH, Bertoni BW, Cestari IM, Espanha LG, Varanda EA, Camilo KFB, Martinez EZ, França SC, Pereira AMS (2017) Lippia origanoides essential oil: an efficient and safe alternative to preserve food, cosmetic and pharmaceutical products. Journal of Applied Microbiology 122:900-910. https://doi.org/ 10.1111/jam.13398

Higuchi R, Kubota S, Komori T, Kawasaki T, Pandey VB, Singh JP, Shah AH (1984) Triterpenoid saponins from the bark of Zizyphus joazeiro. Phytochemistry 23:25972600. https://doi.org/10.1016/S00319422(00)84106-0

Kleinman A (1978) Concepts and a model for the comparison of medical systems as cultural systems. Social Science \& Medicine 12:85-93. https://doi.org/10.1016/01607987(78)90014-5

Laddha AP, Kulkarni YA (2019) Tannins and vascular complications of diabetes: an update. Phytomedicine 56:229-245. https:// doi.org/10.1016/j.phymed.2018.10.026

Lanzotti V (2013) Diterpenes for Therapeutic use. In: Ramawat K, Mérillon JM (eds) Natural Products. Springer, Berlin, Heidelberg.

Larson EC, Hathaway LB, Lamb JG, Pond CD, Rai PP, Matainaho TK, Piskaut P, Barrows LR, Frankllin MR (2014) Interactions of Papua New Guinea medicinal plant extracts with antiretroviral therapy. Journal of Ethnopharmacology 155:1433-1440. https:// doi.org/10.1016/j.jep.2014.07.023

Le Bars D, Gozariu M, Cadden SW (2001) Animal models of nociception. Pharmacological Reviews 53:597-652.

Le NHT, Malterud KE, Diallo D, Paulsen BS, Nergård CS, Wangensteen H (2012) Bioactive polyphenols in Ximenia americana and the traditional use among Malian healers. Journal of Ethnopharmacology 139:858-862. https:// doi.org/10.1016/j.jep.2011.12.031 
Leal LKAM, Canuto KM, Costa KCS, NobreJúnior HV, Vasconcelos SM, Silveira ER, Ferreira MVP, Fontenele JB, Andrade GM, de Barros Viana GS (2009) Effects of Amburoside A and Isokaempferide, Polyphenols from Amburana cearensis, on Rodent Inflammatory Processes and Myeloperoxidase Activity in Human Neutrophils. Basic \& Clinical Pharmacology \& Toxicology 104:198-205. https:// doi.org/10.1111/j.1742-7843.2008.00329.x

Leal LKAM, Fonseca FN, Pereira FA, Canuto KM, Felipe CFB, Fontenele JB, Pitombeira MV, Silveira ER, Viana GSB (2008) Protective effects of amburoside $A$, a phenol glucoside from Amburana cearensis, against $\mathrm{CCl}$ induced hepatotoxicity in rats. Planta Medica 74:497-502. https://doi.org/10.1055/s-20081074501

Leal LKAM, Júnior HVN, Cunha GMA, Moraes MO, Pessoa C, Oliveira RA, Silveira ER, Canuto KM, Viana GSB (2005) Amburoside A, a glucoside from Amburana cearensis, protects mesencephalic cells against 6hydroxydopamine-induced neurotoxicity. Neuroscience Letters 388:86-90. https://doi.org/ 10.1016/J.NEULET.2005.06.034

Leal LKAM, Nechio M, Silveira ER, Canuto KM, Fontenele JB, Ribeiro RA, Viana GSB (2003) Anti-inflammatory and smooth muscle relaxant activities of the hydroalcoholic extract and chemical constituents from Amburana cearensis A. C. Smith. Phytotherapy Research 17:335-340. https:// doi.org/10.1002/ptr.1139

Lev E (2003) Traditional healing with animals (zootherapy): medieval to present-day Levantine practice. Journal of Ethnopharmacology 85:107-118.

Lima Pereira EP, Souza CS, Amparo J, Ferreira RS, Nunez-Figueredo Y, Gonzaga Fernandez L, Ribeiro PR, Braga-de-Souza S, Silva VDA, Costa SL (2017) Amburana cearensis seed extract protects brain mitochondria from oxidative stress and cerebellar cells from excitotoxicity induced by glutamate. Journal of Ethnopharmacology 209:157-166. https:// doi.org/10.1016/j.jep.2017.07.017

Lima RF, Alves ÉP, Rosalen PL, Ruiz ALTG, Duarte MCT, Góes VFF, Medeiros ACD, Pereira JV, Godoy GP, Melo de Brito Costa EM (2014) Antimicrobial and Antiproliferative Potential of Anadenanthera colubrina (Vell.) Brenan. Evidence-Based Complementary Alternative Medicine 2014:1-7. https://doi.org/ $10.1155 / 2014 / 802696$
Lima SMQ, Ramos TPA, Silva MJ, Rosa RS (2017) Diversity, distribution, and conservation of the Caatinga fishes: Advances and challenges. In: Silva JMC, Leal IR, Tabarelli M (eds) Caatinga: The largest tropical dry forest region in South America. Springer, Basel, Switzerland, pp. 97-131.

Lima verde PT, Nascimento NRF, Evangelista JSAM, Tomé AR, Fonteles MC, Santos CF, Cardi $\mathrm{BA}$, Carvalho KM (2009) Isolation and pharmacological effects of leptoxin, a novel proteic toxin from Leptodactylus pentadactylus skin secretion. Toxicon 54:531538.

Lins-Neto EMF, Peroni N, Albuquerque UP (2010) Traditional Knowledge and Management of Umbu (Spondias tuberosa, Anacardiaceae): An Endemic Species from the Semi-Arid Region of Northeastern Brazil. Economic Botany 64:11-21. https://doi.org/ 10.1007/s12231-009-9106-3

Lira SM, Canabrava NV, Benjamin SR, Silva JYG, Viana DA, Lima CLS, Paredes PFM, Marques MMM, Pereira EO, Queiroz EAM, Guedes MIF (2017) Evaluation of the toxicity and hypoglycemic effect of the aqueous extracts of Cnidoscolus quercifolius Pohl. Brazilian Journal of Medical and Biological Research 50(10). https://doi.org/10.1590/1414$431 \times 20176361$

Lopes AA, Magalhães TR, Andrade Uchôa DE, Silveira ER, Azzolini AECS, Kabeya LM, Lucisano-Valim YM, Vasconcelos SMM, Viana GSB, Leal LKAM (2013) Afrormosin, an Isoflavonoid from Amburana cearensis A. C. Smith, Modulates the Inflammatory Response of Stimulated Human Neutrophils. Basic \& Clinical Pharmacology \& Toxicology 113:363369. https://doi.org/10.1111/bcpt.12106

Lopes DM, Júnior NEG, Costa PPC, Martins PL, Santos CF, Carvalho EDF, Carvalho MDF, Pimenta DC, Cardi BA, Fonteles MC, Nascimento NRF, Carvalho KM (2014) A new structurally atypical bradykinin-potentiating peptide isolated from Crotalus durissus cascavella venom (South American rattlesnake). Toxicon 90:36-44.

Lorenzi H, Matos FJ (2002) Medicinal plants in Brazil: Native and exotic cultivated. Plantarum Institute of Flora Studies, São Paulo, Brazil. 
Lucena RFP, de Medeiros PM, Araújo EL, Alves ÂGC, Albuquerque UP (2012) The ecological apparency hypothesis and the importance of useful plants in rural communities from Northeastern Brazil: An assessment based on use value. Journal of Environmental Economics and Management 96:106-115. https://doi.org/ 10.1016/j.jenvman.2011.09.001

Lucena RFP, Nascimento VT, Araújo EL, Albuquerque UP (2008) Local Uses of Native Plants in an Area of Caatinga Vegetation (Pernambuco, NE Brazil). Ethnobotany Research and Applications 6:3-14.

Macedo Pereira G, Moreira LGL, Neto TDSN, Moreira de Almeida WA, Almeida-Lima J, Rocha HAO, Barbosa EG, Zuanazzi JAS, de Almeida MV, Grazul RM, Navarro-Vázquez A, Hallwass F, Ferreira LS, Fernandes-Pedrosa MF, Giordani RB (2018) Isolation, spectral characterization, molecular docking, and cytotoxic activity of alkaloids from Erythroxylum pungens O.E.Shulz. Phytochemistry, 155, 12-18. http://doi: 10.1016/j.phytochem.2018.07.003

Magalhães KN, Guarniz WAS, Sá KM, Freire AB, Monteiro MP, Nojosa RT, Bieski IGC, Custódio JB, Balogun SO, Bandeira MAM (2019) Medicinal plants of the Caatinga, northeastern Brazil: Ethnopharmacopeia (1980-1990) of the late professor Francisco José de Abreu Matos. Journal of Ethnopharmacology 237:314-353. https://doi.org/ 10.1016/J.JEP.2019.03.032

Mahawar MM, Jaroli DP (2006) Animals and their products utilized as medicine by the inhabitants surrounding the Ranthambhore National Park, India. Journal of Ethnobiology and Ethnomedicine 2:1-5.

Mahawar MM, Jaroli DP (2008) Traditional zootherapeutic studies in India: a review. Journal of Ethnobiology and Ethnomedicine 4(1): 17.

Maia-Silva C, Silva Cl, Hrncir M, Queiroz RT, Imperatriz-Fonseca VL (2012) Guia de plantas: visitadas por abelhas na caatinga. Fundação Brasil Cidadão.

Makkar HPS, Siddhuraju P, Becker K (2007) Alkaloids. In: Plant Secondary Metabolites. Methods in Molecular Biology, Humana Press Inc., Totowa, New Jersey.

Marchioro M, Blank MFA, Mourão RHV, Antoniolli AR (2005) Anti-nociceptive activity of the aqueous extract of Erythrina velutina leaves. Fitoterapia 76:637-642. https://doi.org/10.1016/ j.fitote.2005.07.002
Martin-Eauclaire M-F, Bougis PE, Lima ME (2018) Ts1 from the Brazilian scorpion Tityus serrulatus: A half-century of studies on a multifunctional beta like-toxin. Toxicon 152:106-120. https://doi.org/10.1016/j.toxicon. 2018.07.024

Martínez GJ (2013) Use of fauna in the traditional medicine of native Toba (qom) from the Argentine Gran Chaco region: an ethnozoological and conservationist approach. Ethnobiology and Conservation 2(2): $1-43$.

Matos AA, Oliveira FA, Machado AC, Saldanha LL, Tokuhara CK, Souza LP, Vilegas W, Dionísio TJ, Santos C, Peres-Buzalaf C, Dokkedal AL, Oliveira R (2019) An extract from Myracrodruon urundeuva inhibits matrix mineralization in human osteoblasts. Journal of Ethnopharmacology 237:192-201. https:// doi.org/10.1016/j.jep.2019.03.052

Medeiros CD, Falcão HM, Almeida-Cortez J, Santos DYAC, Oliveira AFM, Santos MG (2017) Leaf epicuticular wax content changes under different rainfall regimes, and its removal affects the leaf chlorophyll content and gas exchanges of Aspidosperma pyrifolium in a seasonally dry tropical forest. South African Journal of Botany. 111:267-274. http://doi.org/ 10.1016/j.sajb.2017.03.033

Medeiros PM, Ladio AH, Santos AMM, Albuquerque UP (2013) Does the selection of medicinal plants by Brazilian local populations suffer taxonomic influence? Journal of Ethnopharmacology 146:842-852. https://doi.org/10.1016/j.jep.2013.02.013

Medeiros PM, Pinto BLS, Nascimento VT (2015) Can organoleptic properties explain the differential use of medicinal plants? Evidence from Northeastern Brazil. Journal of Ethnopharmacology 159:43-48. https://doi.org/ 10.1016/j.jep.2014.11.001

Medeiros MF, Silva PS, Albuquerque UP (2011a) Quantification in ethnobotanical research: an overview of indices used from 1995 to 2009. Sitientibus. Série Ciências Biológicas 11: 211230.

Medeiros VM, Fernandes HMB, Sousa DF, Queiroga KF, Cabral AGS, Costa VCO, BarbosaFilho JM, Tavares JF, Silva MS (2011b) Diterpenos clerodanos de Croton grewioides Baill. (Euphorbiaceae). 34a Reunião Anual da Sociedade Brasileira de Química, Florianópolis, SC, Brasil. 
Meira CS, Guimarães ET, Macedo TS, Silva TB, Menezes LRA, Costa EV, Soares MBP (2015) Chemical composition of essential oils from Annona vepretorum Mart. and Annona squamosa L. (Annonaceae) leaves and their antimalarial and trypanocidal activities. Journal of Essential Oil Research 27:160-168. https://doi.org/10.1080/10412905.2014.982876

Melo FPL (2017) The socio-ecology of the Caatinga: Understanding how natural resource use shapes an ecosystem. In: Silva JMC, Leal IR, Tabarelli M (eds) Caatinga: The largest tropical dry forest region in South America. Springer, Basel, Switzerland, pp. 369382.

Mello JPC, Santos SC (2001) Farmacognosia: da planta ao medicamento. Simões, C.M.O., Schenckel, E.P., orgs.; Ed. UFSC. 3 ed. Porto Alegre.

Mendonça LET, Vieira WLS, Alves RRN (2014) Caatinga Ethnoherpetology: relationships between herpetofauna and people in a semiarid region. Amphibian \& Reptile Conservation 8(1):24-32.

Menezes PMN, Brito MC, Paiva GO, Santos CO, Oliveira LM, Ribeiro LAA, Lima JT, Lucchese AM, Silva FS (2018) Relaxant effect of Lippia origanoides essential oil in guinea-pig trachea smooth muscle involves potassium channels and soluble guanylyl cyclase. Journal of Ethnopharmacology 220:16-25. https://doi.org/10.1016/j.jep.2018.03.040

Mesquita DO, Costa GC, Garda AA, Delfim FR (2017) Species composition, biogeography, and conservation of the Caatinga lizards. In: Silva JMC, Leal IR, Tabarelli M (eds) Caatinga: The largest tropical dry forest region in South America. Springer, Basel, Switzerland, pp. 151180.

Molares S, Ladio A (2008) Plantas medicinales en una comunidad Mapuche del NO de la Patagonia Argentina: classificación y percepciones organolépticas relacionadas com su valoración. Boletín Latinoamericano y del Caribe de Plantas Medicinales y Aromáticas 7:149-155.

Montanari CA, Bolzani VS (2001) Planejamento racional de fármacos baseado em produtos naturais. Química Nova 24:105-111. http:// doi.org/10.1590/S0100-40422001000100018
Monteiro JM, Albuquerque UP, Araújo EL, Amorim ELC (2005) Taninos: Uma abordagem da química à ecologia. Química Nova 28:892896. 40422005000500029

Monteiro JM, Albuquerque UP, Lins-Neto EMF, Araújo EL, Albuquerque MM, Amorim ELC (2006a) The effects of seasonal climate changes in the Caatinga on tannin levels in Myracrodruon urundeuva (Engl.) Fr. All. and Anadenanthera colubrina (Vell.) Brenan. Brazilian Journal of Pharmacognosy 16:338344.

Monteiro JM, Albuquerque UP, Lins-Neto EMF, Araújo EL, Amorim ELC (2006b) Use patterns and knowledge of medicinal species among two rural communities in Brazil's semi-arid northeastern region. Journal of Ethnopharmacology 105:173-186. https://doi.org/ 10.1016/j.jep.2005.10.016

Monteiro JM, Lins-Neto EMF, Amorim ELC, Strattmann RR, Araújo EL, Albuquerque UP (2005) Teor de taninos em três espécies medicinais arbóreas simpátricas da Caatinga. Revista Árvore 29:999-1005.

Monteiro JM, Souza JSN, Lins-Neto EMF, Scopel K, Trindade EF (2014) Does total tannin content explain the use value of spontaneous medicinal plants from the Brazilian semi-arid region? Revista Brasileira de Farmácia 24:116123. http://doi.org/10.1016/j.bjp.2014.02.001

Moretão MP, Buchi DF, Gorin PAJ, lacomini M, Oliveira MBM (2003) Effect of an acidic heteropolysaccharide (ARAGAL) from the gum of Anadenanthera colubrina (Angico branco) on peritoneal macrophage functions. Immunology Letters 89:175-185.

Moretão MP, Zampronio AR, Gorin PA, lacomini M, Oliveira MBM (2004) Induction of secretory and tumoricidal activities in peritoneal macrophages activated by an acidic heteropolysaccharide (ARAGAL) from the gum of Anadenanthera colubrina (Angico branco). Immunology Letters 93:189-197. https://doi.org/10.1016/j.imlet.2004.03.021

Mota GS, Sartori CJ, Miranda I, Quilhó T, Mori FA, Pereira H (2017) Bark anatomy, chemical composition and ethanol-water extract composition of Anadenanthera peregrina and Anadenanthera colubrina. PLoS One 12:e0189263. https://doi.org/10.1371/ 
Moura FBP, Marques JGW (2008) Zooterapia popular na Chapada Diamantina: uma Medicina incidental? Ciência \& Saúde Coletiva 13:2179-2188.

Murray J, Picking D, Lamm A, McKenzie J, Hartley S, Watson C, Williams L, Lowe H, Delgoda R (2016) Significant inhibitory impact of dibenzyl trisulfide and extracts of Petiveria alliacea on the activities of major drugmetabolizing enzymes in vitro: An assessment of the potential for medicinal plant-drug interactions. Fitoterapia 111:13846. https://doi.org/10.1016/j.fitote.2016.04.011

Nagata JM, Jew AR, Kimeu JM, Salmen CR, Bukusi EA, Cohen CR (2011) Medical pluralism on Mfangano Island: Use of medicinal plants among persons living with HIVIAIDS in Suba District, Kenya. Journal of Ethnopharmacology 135:501-509. https://doi.org/10.1016/j.jep. 2011.03.051

Nascimento ALB, Lozano A, Melo JG, Alves RRN, Albuquerque UP (2016) Functional aspects of the use of plants and animals in local medical systems and their implications for resilience. Journal of Ethnopharmacology 194:348-357. http://doi.org/10.1016/j.jep. 2016.08.017

Nascimento ALB, Medeiros PM, Albuquerque UP (2018) Factors in hybridization of local medical systems: Simultaneous use of medicinal plants and modern medicine in Northeast Brazil. PLoS ONE 13:e0206190. https://doi.org/10.1371/journal.pone.0206190

Nascimento-Silva O, Leite DS, Bernardes LA, Paiva JGA (2011) Morphology, anatomy, and histochemistry of the leaves of Myracrodruon urundeuva Allemão (Anacardiaceae). Boletín Latinoamericano y del Caribe de Plantas Medicinales y Aromáticas 10:56-66.

Negreiros Neto TS, Gardner D, Hallwass F, Leite AJM, Almeida CG, Silva LM, Roque AA, Bitencourt FG, Barbosa EG, Tasca T, Macedo AJ, Almeida MV, Giordani RB (2016) Activity of pyrrolizidine alkaloids against biofilm formation and Trichomonas vaginalis. Biomedicine and Pharmacotherapy 83:323-329. http://doi.org/10.1016/j.biopha.2016.06.033

Neves IA, da Camara CAG (2012) Volatile constituents of two Croton species from Caatinga biome of Pernambuco-Brasil. Records of Natural Products 6:161-165.
Neves IA, Oliveira JCS, Camara CAG (2008) Chemical composition of the leaf oils of Lippia gracilis Schauer from two localities of Pernambuco. Journal of Essential Oil Research 20:157-160.

10.1080/10412905.2008.9699979 http://doi.org/

Newman DJ, Cragg GM (2016) Natural Products as Sources of New Drugs from 1981 to 2014. Journal of Natural Products 79:629661.

Niwa Y, Suzuki T, Dohmae N, Umezawa K, Simizu S (2012) Determination of cathepsin V activity and intracellular trafficking by $\mathrm{N}$ glycosylation. FEBS Letters 586:3601-3607. https://doi.org/10.1016/j.febslet.2012.08.001

Nobre-Júnior HV, Oliveira RA, Maia FD, Nogueira MAS, Moraes MO, Bandeira MAM, Andrade GM, Viana GSB (2009) Neuroprotective Effects of Chalcones from Myracrodruon urundeuva on 6Hydroxydopamine-Induced Cytotoxicity in Rat Mesencephalic Cells. Neurochemical Research 34:1066-1075. https://doi.org/10.1007/ s11064-008-9876-5

Nogueira PCN, Araújo RM, Viana GSB, De Araújo DP, Filho RB, Silveira ER (2014) Plumeran alkaloids and glycosides from the seeds of Aspidosperma pyrifolium Mart. Journal of the Brazilian Chemical Society 11:2108-2212. http://doi.org/10.5935/01035053.20140204

Nunes PH, Marinho LC, Nunes ML, Soares EO (1987) Antipyretic activity of an aqueous extract of Zizyphus joazeiro Mart. (Rhamnaceae). Brazilian Journal of Medical and Biological Research 20:599-601.

Ogunleye DS, Ibitoye SF (2003) Studies of antimicrobial activity and chemical constituents of Ximenia americana. Tropical Journal of Pharmaceutical Research 2(2):239241.

Oh YJ, Wong SC, Moffat M, O'Malley KL (1995) Overexpression of $\mathrm{Bcl}-2$ attenuates MPP+, but not 6-ODHA, induced cell death in a dopaminergic neuronal cell line. Neurobiology of Disease 2:157-167.

Olinda ACC (2010) Estudo da atividade antinociceptiva de um novo fator extraído do veneno de Crotalus durissus collilineatus. Programa de Pós-graduação em Ciências Fisiológicas (Master Science Dissertation), Universidade Estadual do Ceará, Fortaleza-CE, Brazil, $81 \mathrm{p}$. 
Oliveira Júnior RG, Ferraz CAA, Pereira ECV, Sampaio PA, Silva MFS, Pessoa CO, Rolim LA, Almeida JRGS (2019) Phytochemical analysis and cytotoxic activity of Cnidoscolus quercifolius Pohl (Euphorbiaceae) against prostate (PC3 and PC3-M) and breast (MCF-7) cancer cells. Pharmacognosy 5:24-28. http:// doi.org/10.4103/pm.pm_6_18

Oliveira AFM, Salatino A (2000) Major constituents of the foliar epicuticular waxes of species from the Caatinga and Cerrado. Zeitschrift für Naturforschung C. A Journal of Biosciences 55:688-692. http://doi.org/10.1515/ znc-2000-9-1003

Oliveira AP, Borges IV, Pereira ECV, Feitosa TA, Santos RF, Oliveira-Júnior RG, Rolim LA, Viana LGFC, Ribeiro LAA, Santos ADC, Rolim-Neto PJ, Almeida JRGS (2019) Influence of light intensity, fertilizing and season on the cirsiliol content, a chemical marker of Leonotis nepetifolia (Lamiaceae). PeerJ 7:6187.

Oliveira YLC, Silva LCN, Silva AG, Macedo AJ, Araújo JM, Correia MTS, Silva MV (2012) Antimicrobial activity and phytochemical screening of Buchenavia tetraphylla (Aubl.) R. A. Howard (Combretaceae: Combretoideae). The Scientific World Journal ID 849302. https://doi.org/10.1100/2012/849302

Oliveira DR, Leitão GG, Fernandes PD, Leitão SG, Oliveira DR, Leitão GG, Fernandes PD, Leitão SG (2014) Ethnopharmacological studies of Lippia origanoides. Revista Brasileira de Farmacognosia 24:206-214. https:// doi.org/10.1016/j.bjp.2014.03.001

Oliveira FA, Rorato VC, Almeida-Apolonio AA, Rodrigues $A B$, Barros $A L$, Sangalli $A$, Arena AC, Mota JS, Grisolia AB, Oliveira KMP (2017) In vitro antifungal activity of Myracrodruon urundeuva Allemão against human vaginal Candida species. Anais da Academia Brasileira de Ciências 89:2423-2432. https://doi.org/ 10.1590/0001-3765201720170254

Oliveira OP, Sales DL, Dias DQ, Cabral MES, Araújo-Filho JA, Teles DA, Sousa JGG, Ribeiro SC, Freitas FRD, Coutinho HDM, Kerntopf MR, Costa JGM, Alves RRN, Almeida WO (2014) Antimicrobial activity and chemical composition of fixed oil extracted from the body fat of snake Spilotes pullatus (Linnaeus, 1758) (Colubridae: Ophidia). Pharmaceutical Biology 52:740-744.
Oliveira SL (2012) Fitoquímica de espécies de Erythroxylum do semiárido: isolamento e determinação estrutural de alcaloides tropânicos, flavonoides e diterpenos. (PhD Thesis). Universidade Federal da Paraíba. 192p.

Oliveira-Júnior RG, Alves Ferraz CA, Pontes MC, Cavalcante NB, Pontes M, Cavalcante NB, Araújo EC., de Oliveira AP, Picot L, Rolim LA, Almeida JRGS (2018) Antibacterial activity of terpenoids isolated from Cnidoscolus quercifolius Pohl (Euphorbiaceae), a Brazilian medicinal plant from caatinga biome. European Journal of Integrative Medicine 24:30-34. http://doi.org/10.1016/j.eujim. 2018.10.011

Paredes PFM, Vasconcelos FR, Paim RTT, Marques MMM, De Morais SM, Lira SM, Braquehais ID, Vieira ÍGP, Mendes FNP, Guedes MIF (2016) Screening of Bioactivities and Toxicity of Cnidoscolus quercifolius Pohl. Evidence-Based Complementary Alternative Medicine 2016:1-9. https://doi.org/ 10.1155/2016/7930563

Peixoto Sobrinho TJS, Castro VTNA, Saraiva AM, Almeida DM, Tavares EA, Amorim ELC (2011) Phenolic content and antioxidant capacity of four Cnidoscolus species (Euphorbiaceae) used as ethnopharmacologicals in Caatinga, Brazil. African Journal of Pharmacy and Pharmacology 5:2310-2316. http://doi.org/10.5897/AJPP11.608

Peixoto Sobrinho TJS, Castro VTNA, Saraiva AM, Almeida DM, Tavares EA, Pisciottano MNC, Amorim ELC (2012) Phytochemical screening and antibacterial activity of four Cnidoscolus species (Euphorbiaceae) against standard strains and clinical isolates. Journal of Medicinal Plants Research 6:3742-3748. http:// doi.org/10.5897/JMPR11.1533

Peixoto RM, Lima e Silva WE, Almeida JRGS, Branco A, Costa MM (2016) Antibacterial potential of native plants from the Caatinga biome against Staphylococcus spp. isolates from small ruminants with mastitis. Revista Caatinga 29:758-763. http://doi.org/ 10.1590/1983-21252016v29n328rc

Pereira Gomes-Copeland KK, da Silva Lédo A, de Almeida FTC, Moreira BO, Santos DC, Santos RAF, David JM, David JP (2018) Effect of elicitors in Poincianella pyramidalis callus culture in the biflavonoid biosynthesis. Industrial Crops and Products 126:421-425. http://doi.org/10.1016/j.indcrop.2018.10.038 
Pereira JR, Queiroz RF, Siqueira EA, BrasileiroVidal AC, Sant'ana AEG, Silva DM, Affonso PRAM (2017) Evaluation of cytogenotoxicity, antioxidant and hypoglycemiant activities of isolate compounds from Mansoa hirsuta D.C. (Bignoniaceae). Anais da Academia Brasileira de Ciências 89:317-331.

Pereira EJP, do Vale JPC, da Silva PT, Lima J dos R, Alves DR, Costa PS, Rodrigues THS, Menezes JESA, Morais SM, Bandeira PN, Fontenelle ROS, Santos HS (2018) Circadian Rhythm, and Antimicrobial and Anticholinesterase Activities of Essential Oils from Vitex gardneriana. Natural Product Communications 13:635-638. https://doi.org/ 10.1177/1934578X1801300528

Pereira JV, Freire IA, Castilho AR, Cunha MG, Alves HS, Rosalen PL (2016) Antifungal potential of Sideroxylon obtusifolium and Syzygium cumini and their mode of action against Candida albicans. Pharmaceutical Biology 54:2312-2319. http://doi.org/ 10.3109/13880209.2016.1155629

Pereira S, Figueiredo-Lima K, Oliveira AFM, Santos MG (2019) Changes in foliar epicuticular wax and photosynthesis metabolism in evergreen woody species under different soil water availability. Photosynthetica 57:192-201. http://doi.org/ 10.32615/ps.2019.013

Pervaiz A, Adwan H, Berger MR (2015) Riproximin: A type II ribosome inactivating protein with anti-neoplastic potential induces IL24/MDA-7 and GADD genes in colorectal cancer cell lines. International Journal of Oncology 47:981-990. https://doi.org/10.3892/ijo. 2015.3073

Pervaiz A, Zepp M, Adwan H, Berger MR (2016) Riproximin modulates multiple signaling cascades leading to cytostatic and apoptotic effects in human breast cancer cells. Journal of Cancer Research and Clinical Oncology 142:135-147. https://doi.org/10.1007/s00432015-2013-3

Pessoa WS, Estevão LRM, Simões RS, Barros MEG, Mendonça FS, Baratella-Evêncio L, Evêncio-Neto J (2012) Effects of angico extract (Anadenanthera colubrina var. cebil) in cutaneous wound healing in rats. Acta Cirúrgica Brasileira 27:655-670. https://doi.org/ 10.1590/s0102-86502012001000001
Pessoa WS, Estevão LRM, Simões RS, Mendonça FS, Evêncio-Luz L, Baratella-Evêncio L, Florencio-Silva $R$, Sá FB, Evêncio-Neto J (2015) Fibrogenesis and epithelial coating of skin wounds in rats treated with angico extract (Anadenanthera colubrina var. cebil). Acta Cirúrgica Brasileira 30:353-358. https:// doi.org/10.1590/s0102-865020150050000007

Phillips O, Gentry AH (1993) The useful plants of Tambopata, Peru: I. Statistical hypothesis tests with a new quantitative technique. Economic Botany 47:15-32. https://doi.org/ 10.1007/BF02862203

Pinho RS, Oliveira AFM, Silva SI (2009) Potential oilseed crops from the semiarid region of northeastern Brazil. Bioresource Technology 100:6114-6117. http://doi.org/ 10.1016/j.biortech.2009.06.010

Pires AML, Pessoa ODL, Silveira ER, Braz-Filho R (2011) Diterpenos cassanos de Calliandra depauperata. 34a Reunião Anual da Sociedade Brasileira de Química, Florianópolis, SC, Brasil.

Pucca MB, Peigneur S, Cologna CT, Cerni FA, Zoccal KF, Bordon KCF, Faccioli LH, Tytgat J, Arantes EC (2015) Electrophysiological characterization of the first Tityus serrulatus alpha-like toxin, Ts5: Evidence of a proinflammatory toxin on macrophages. Biochimie 115:8-16. https://doi.org/10.1016/ j.biochi.2015.04.010

Queiroz LP, Cardoso D, Fernandes MF, Moro MF (2017) Diversity and evolution of flowering plants of the Caatinga domain. In: Silva JMC, Leal IR, Tabarelli M (eds) Caatinga: The largest tropical dry forest region in South America. Springer, Basel, Switzerland, pp. 23-63.

Rabêlo SV, Costa EV, Barison A, Dutra LM, Nunes XP, Tomaz JC, Oliveira GG, Lopes NP, Santos MFC, Almeida JR (2015) Alkaloids isolated from the leaves of atemoya (Annona cherimola x Annona squamosa). Brazilian Journal of Pharmacognosy 25:419-421. http:// dx.doi.org/10.1016/j.bjp.2015.07.006

Rahman K, Khan SU, Fahad S, Chang MX, Abbas A, Khan WU, Rahman L, Haq ZU, Nabi G, Khan D (2019) Nano-biotechnology: a new approach to treat and prevent malaria. International Journal of Nanomedicine 14:14011410. https://doi.org/10.2147//JN.S190692 
Raman V, Aryal UK, Hedrick V, Ferreira RM, Fuentes Lorenzo JL, Stashenko EE, Levy M, Levy MM, Camarillo IG (2018) Proteomic Analysis Reveals That an Extract of the Plant Lippia origanoides Suppresses Mitochondrial Metabolism in Triple-Negative Breast Cancer Cells. Journal of Proteome Research 17:33703383. https://doi.org/10.1021/acs.jproteome. $8 b 00255$

Raman V, Lorenzo JLF, Stashenko EE, Levy M, Levy MM, Camarillo IG (2017) Lippia origanoides extract induces cell cycle arrest and apoptosis and suppresses NF-KB signaling in triple-negative breast cancer cells. International Journal of Oncology 51:18011808. https://doi.org/10.3892/ijo.2017.4169

Ramos JMO, Santos CA, Santana DG, Santos DA, Alves PB, Thomazzi SM (2013) Chemical constituents and potential anti-inflammatory activity of the essential oil from the leaves of Croton argyrophyllus. Brazilian Journal of Pharmacognosy 23:644-650. http://doi.org/ 10.1590/S0102-695X2013005000045

Raupp IM, Sereniki A, Virtuoso S, Ghislandi C, Cavalcanti e Silva EL, Trebien HA, Miguel OG, Andreatini R (2008) Anxiolytic-like effect of chronic treatment with Erythrina velutina extract in the elevated plus-maze test. Journal of Ethnopharmacology 118:295-299. https:// doi.org/10.1016/j.jep.2008.04.016

Ribeiro BD, Barreto DW, Coelho MAZ (2014) Recovery of saponins from jua (Ziziphus joazeiro) by micellar extraction and cloud point preconcentration. Journal of Surfactants and Detergents 17:553-561. https://doi.org/ 10.1007/s11743-013-1526-5

Ribeiro BD, Coelho MAZ, Marucho IM (2013) Extraction of saponins from sisal (Agave sisalana) and juá (Ziziphus joazeiro) with cholinium based ionic liquids and deep eutectic solvents. European Food Research and Technology 237:965-975. https://doi.org/ $10.1007 / \mathrm{s} 00217-013-2068-9$

Ribeiro MD, Onusic GM, Poltronieri SC, Viana MB (2006) Effect of Erythrina velutina and Erythrina mulungu in rats submitted to animal models of anxiety and depression. Brazilian Journal of Medical and Biological Research 39:263-270. https://doi.org//S0100879X2006000200013
Ribeiro PPC, Silva DML, Assis CF, Correia RTP, Damasceno KSFSC (2017) Bioactive properties of faveleira (Cnidoscolus quercifolius) seeds, oil and press cake obtained during oilseed processing. PLoS One 12:e0183935. https://doi.org/10.1371/ journal.pone.0183935

Ribeiro SM, Bonilla OH, Lucena EMP (2018) Influência da sazonalidade e do ciclo circadiano no rendimento e composição química dos óleos essenciais de Croton spp. da Caatinga. Iheringia - Serie Botanica 73:3138. http://doi.org/10.21826/2446-

8231201873104

Riet-Correa F, Medeiros RMT, Schild AL (2012) A review of poisonous plants that cause reproductive failure and malformations in the ruminants of Brazil. Journal of Applied Toxicology 32:245-254. https://doi.org/10.1002/ jat. 1754

Ríos JL, Recio MC (2005) Medicinal plants and antimicrobial activity. Journal of Ethnopharmacology 100:80-84.

Rodrigues FTS, Sousa CNS, Ximenes NC, Almeida AB, Cabral LM, Patrocínio CFV, Silva $\mathrm{AH}$, Leal LKAM, Honório-Júnior JER, Macedo D, Vasconcelos SMM (2017) Effects of standard ethanolic extract from Erythrina velutina in acute cerebral ischemia in mice. Biomedicine \& Pharmacotherapy 96:1230-1239. https:// doi.org/10.1016/j.biopha.2017.11.093

Rodrigues LV, Ferreira FV, Regadas FSP, Matos D, Viana GSB (2002) Morphologic and morphometric analyses of acetic acidinduced colitis in rats after treatment with enemas from Myracrodruon urundeuva Fr. All. (Aroeira do Sertão). Phytotherapy Research 16:267-272. https://doi.org/10.1002/ ptr.841

Sá RA, Santos NDL, Silva CSB, Napoleão TH, Gomes FS, Cavada BS, Coelho LCBB, Navarro DMAF, Bieber LW, Paiva PMG (2009) Larvicidal activity of lectins from Myracrodruon urundeuva on Aedes aegypti. Comparative Biochemistry \& Physiology Part C: Toxicology and Pharmacology 149:300-306. https://doi.org/ 10.1016/j.cbpc.2008.08.004 
Sales DL, Morais-Braga MFB, Santos ATL, Machado AJT, Araújo-Filho JA, Dias DQ, Cunha FAB, Saraiva RA, Menezes IRA, Coutinho HDM, Costa JGM, Ferreira FS, Alves RRN, Almeida WO (2017) Antibacterial, modulation activity of antibiotics and toxicity from Rhinella jimi (Stevaux, 2002) (Anura: Bufonidae) glandular secretions. Biomedicine \& Pharmacotherapy 92:554-561.

Sales DL, Oliveira OP, Cabral MES, Dias DQ, Kerntopf MR, Coutinho HDM, Costa JGM, Freitas FRD, Ferreira FS, Alves RRN, Almeida WO (2015) Chemical identification and evaluation of the antimicrobial activity of fixed oil extracted from Rhinella jimi. Pharmaceutical Biology 53:98-103.

Santoro FR, Ferreira Júnior WS, Araújo TAS, Ladio AH, Albuquerque UP (2015) Does plant species richness guarantee the resilience of local medical systems? A perspective from utilitarian redundancy. PLoS One 10:e0119826. https://doi.org/10.1371/ journal.pone.0119826

Santoro FR, Nascimento ALB, Soldati GT, Ferreira Júnior WS, Albuquerque UP (2018) Evolutionary ethnobiology and cultural evolution: opportunities for research and dialog. Journal of Ethnobiology and Ethnomedicine 14:1. https://doi.org/10.1186/ s13002-017-0199-y

Santos CAB, Alves RRN (2016) Ethnoichthyology of the indigenous Truká people, Northeast Brazil. Journal of Ethnobiology and Ethnomedicine 12(1): 1-12.

Santos GID, Lemos EL, Fernandes AC. Rocha WRV, Catão RMR, Braz-Filho R, Tavares JF, Fechine IM, Alves HS (2018) Phytochemical study of Harrisia adscendens. Revista Brasileira de Farmacognosia 28:298-302. http:// dx.doi.org/10.1016/j.bjp.2018.04.011

Santos IJM, Coutinho HDM, Matias EFF, Costa JGM, Alves RRN, Almeida WO (2012a) Antimicrobial activity of natural products from the skins of semiarid living lizards Ameiva ameiva (Linnaeus, 1758) and Tropidurus hispidus (Spix, 1825). Journal of Arid Environments 76:138-141.

Santos IJM, leite GO, Costa JGM, Alves RRN, Campos AR, Menezes IRA, Freita FRV, Nunes MJH, Almeida WO (2015) Topical antiinflammatory activity of oil from Tropidurus hispidus (Spix, 1825). Evidence-based Complementary Alternative Medicine 2015:1-7. https://doi.org/10.1155/2015/140247
Santos IJM, Matias EFF, Santos KKA, Braga MFBM, Andrade JC, Souza TM, Santos FAV, Sousa ACA, Costa JGM, Menezes IRA, Alves RRN, Almeida WO, Coutinho HDM (2012b) Evaluation of the antimicrobial activity of the decoction of Tropidurus hispidus (Spix, 1825) and Tropidurus semitaeniatus (Spix, 1825) used by the traditional medicine. Evidencebased Complementary and Alternative Medicine 2012:1-6. https://doi.org/10.1155/2012/747969

Santos JS, Marinho RR, Ekundi-Valentim E, Rodrigues L, Yamamoto MH, Teixeira SA, Muscara MN, Costa SK, Thomazzi SM (2013) Beneficial effects of Anadenanthera colubrina (Vell.) Brenan extract on the inflammatory and nociceptive responses in rodent models. Journal of Ethnopharmacology 148:18-222. https://doi.org/https://doi.org/ 10.1016/j.jep.2013.04.012

Saslis-Lagoudakis $\mathrm{CH}$, Savolainen V, Williamson EM, Forest F, Wagstaff SJ, Baral SR, Watson MF, Pendry CA, Hawkins JA (2012) Phylogenies reveal predictive power of traditional medicine in bioprospecting. PNAS109(39):15835-15840. doi:10.1073/ pnas. 1202242109

Saraiva AM, Castro RHA, Cordeiro RP, Sobrinho TJSP, Castro VTNA, Amorim ELC, Xavier HS, Pisciottano MNC (2011) In vitro evaluation of antioxidant, antimicrobial and toxicity properties of extracts of Schinopsis brasiliensis Engl. (Anacardiaceae). African Journal of Pharmacy and Pharmacology 5:17241731.

Sarria ALF, Silva TL, Oliveira JM, Oliveira MAR, Fernandes JB, Silva MFGF, Vieira PC, Venancio T, Alves Filho EG, Batista JM, Guido RVC (2018) Dimeric chalcones derivatives from Myracrodruon urundeuva act as cathepsin V inhibitors. Phytochemistry 154:31-38. https:// doi.org/10.1016/j.phytochem.2018.06.009

Siddaiah M, Souris K, Janapati $\mathrm{Y}$, Vasanth Kumar P (2019) Phytochemical Screening and Anti Diabetic Activity of Methanolic Extract of Leaves of Ximenia americana in Rats. International Journal of Innovative Pharmaceutical Research 2(1):78-83. 
Silva Pantoja Pd, Assreuy AMS, Silva RO, Damasceno SRB, Mendonça VA, Mendes TS, Morais JAV, de Almeida SL, Teixeira AÉEA, de Souza MHLP, Pereira MG, Soares PMG (2018) The polysaccharide-rich tea of Ximenia americana barks prevents indomethacininduced gastrointestinal damage via neutrophil inhibition. Journal of Ethnopharmacology 224:195-201. https://doi.org/ 10.1016/j.jep.2018.05.041

Silva Siqueira EM, Félix-Silva J, Araújo LML, Fernandes JM, Cabral B, Gomes JADS, Araújo Roque A, Tomaz JC, Lopes NP, FernandesPedrosa MF, Giordani RB, Zucolotto SM (2016) Spondias tuberosa (Anacardiaceae) leaves: profiling phenolic compounds by HPLC-DAD and LC-MS/MS and in vivo anti-inflammatory activity. Biomedical Chromatography 30:165665. https://doi.org/10.1002/bmc.3738

Silva ARA, Morais SM, Marques MMM, Oliveira DF, Barros CC, Almeida RR, Vieira ÍGP, Guedes MIF (2012a) Chemical composition, antioxidant and antibacterial activities of two Spondias species from Northeastern Brazil. Pharmaceutical Biology 50:740-746. https:// doi.org/10.3109/13880209.2011.627347

Silva AG, Silva LCN, Filho CMB, Araújo DRC, Silva JFV, Arruda IR, Araújo JM, Correia MTS, Macedo AJ, Silva MV (2012b) Antimicrobial activity of medicinal plants of the Caatinga (semi-arid) vegetation of NE Brazil. Current Topics in Phytochemistry 11:81-94.

Silva MS, Brando DO, Chaves TP, Formiga Filho AL, Costa EM, Santos VL, Medeiros AC (2012c) Study bioprospecting of medicinal plant extracts of the semiarid northeast: Contribution to the control of oral microorganisms.

Evidence-based Complementary and Alternative Medicine ID 681207. https://doi.org/10.1155/2012/681207

Silva ACO, Oliveira AFM, Santos DYAC, Silva SI (2010) An approach to chemotaxonomy to the fatty acid content of some Malvaceae species. Biochemical Systematics and Ecology 38:1-4. http://doi.org/10.1016/j.bse.2010.10.006

Silva AH, Fonseca FN, Pimenta ATÁ, Lima MS, Silveira ER, Viana GSB, Vasconcelos SMM, Leal LKAM (2016) Pharmacognostical Analysis and Protective Effect of Standardized Extract and Rizonic Acid from Erythrina velutina against 6-Hydroxydopamine-Induced Neurotoxicity in SH-SY5Y Cells. Pharmacognosy 12:307-312. https://doi.org/10.4103/0973-1296.192200
Silva BAFd, Costa RHS, Fernandes CN, Leite LHI, Ribeiro-Filho J, García TR, Coutinho HDM, Wanderley AG, de Menezes IRA (2018) HPLC profile and antiedematogenic activity of Ximenia americana L. (Olacaceae) in mice models of skin inflammation. Food and Chemical Toxicology 119:199-205. https:// doi.org/10.1016/j.fct.2018.04.041

Silva CG, Marinho MGV, Lucena MFA, Costa JGM (2015) Ethnobotanical survey of medicinal plants in the caatinga area in the community of sitio Nazaré, Milagres, Ceará, Brazil. Revista Brasileira de Plantas Medicinais 17:133-142. http://doi.org/10.1590/1983-084X/ 12_055

Silva FO, Oliveira IR, Silva MGV, Braz-Filho R (2010) Constituintes químicos das folhas de Senna spectabilis (DC) Irwin \& Barneby var. excelsa (Schrad.) Irwin \& Barneby. Química Nova 33:1874-1876. http://dx.doi.org/10.1590/ S0100-40422010000900010

Silva JC, Araújo CS, Lima-Saraiva SRG, Oliveira-Júnior RG, Diniz TC, Wanderley CWS, Palheta-Júnior RC, Mendes RL, Guimarães AG, Quintans-Júnior LJ, Almeida JRGS (2015) Antinociceptive and anti-inflammatory activities of the ethanolic extract of Annona vepretorum Mart. (Annonaceae) in rodents. BMC Complementary Alternative Medicine 15:197. https://doi.org/10.1186/S12906-0150716-2

Silva SI, Oliveira AFM, Negri G, Salatino A (2014) Seed oils of Euphorbiaceae from the Caatinga, a Brazilian tropical dry forest. Biomass and Bioenergy 69:124-134. http:// doi.org/10.1016/j.biombioe.2014.07.010

Silva TCL, Almeida CCBR, Veras Filho J, Peixoto Sobrinho TJS, Amorim ELC, Costa EP, Araújo JM (2011) Atividades antioxidante e antimicrobiana de Ziziphus joazeiro mart. (Rhamnaceae): avaliação comparativa entre cascas e folhas. Revista de Ciências Farmacêuticas Básica e Aplicada 32(2):193199.

Silva JMC, Leal IR, Tabarelli M (2017a) Caatinga: The largest tropical dry forest region in South America. Springer, Basel, Switzerland.

Silva JMC, Barbosa LCF, Leal IR, Tabarelli M (2017b) The Caatinga: Understanding the Challenges. In: Silva JMC, Leal IR, Tabarelli M (eds) Caatinga: The largest tropical dry forest region in South America. Springer, Basel, Switzerland, pp. 3-19. 
Silva-Leite KESd, Girão DKFB, Freitas Pires A, Assreuy AMS, de Moraes PAF, Cunha AP, Ricardo NMPS, Criddle DN, de Souza MHLP, Pereira MG, Soares PMG (2018) Ximenia americana heteropolysaccharides ameliorate inflammation and visceral hypernociception in murine caerulein-induced acute pancreatitis: Involvement of CB2 receptors. Biomedicine \& Pharmacotherapy 106:13171324.

2018.07.067

Siqueira CF, Cabral DL, Peixoto Sobrinho TJ, Amorim EL, Melo JG, Araújo TA, Albuquerque UP (2012) Levels of tannins and flavonoids in medicinal plants: evaluating bioprospecting strategies. Evidence-Based Complementary and Alternative Medicine ID 434782. https:// doi.org/10.1155/2012/434782

Sivira A, Sanabria M, Valera N, Vásquez C (2011) Toxicity of ethanolic extracts from Lippia origanoides and Gliricidia sepium to Tetranychus cinnabarinus (Boisduval) (Acari: Tetranychidae). Neotropical Entomology 40:375$379 . \quad$ https://doi.org/10.1590/s1519$566 \times 2011000300011$

Soares AMS, Oliveira JTA, Rocha CQ, Ferreira ATS, Perales J, Zanatta AC, Vilegas W, Silva CR, Costa-Júnior LM (2018) Myracrodruon urundeuva seed exudates proteome and anthelmintic activity against Haemonchus contortus. PLoS One 13:e0200848. https:// doi.org/10.1371/journal.pone.0200848

Sobeh M, Mahmoud MF, Abdelfattah MAO, ElBeshbishy HA, El-Shazly AM, Wink M (2017) Hepatoprotective and hypoglycemic effects of a tannin rich extract from Ximenia americana var. caffra root. Phytomedicine 33:36-42. 2017.07.003

Soldati GT, Albuquerque UP (2012) A new application for the optimal foraging theory: the extraction of medicinal plants. EvidenceBased Complementary and Alternative Medicine 2012:364564. $10.1155 / 2012 / 364564$

Soro TY, Zahoui OS, Nene-Bi AS, Traore F (2016) Analgesic activity of the fractions of the aqueous extract of Ximenia americana (Linné) (Olacaceae). International Journal of Pharmacology and Toxicology 4:1. https://doi.org/ 10.14419/ijpt.v4i1.5513
Sousa DCP, Soldati GT, Monteiro JM, Araújo TAS, Albuquerque UP (2016) Information Retrieval during Free Listing Is Biased by Memory: Evidence from Medicinal Plants. PLoS One 11:e0165838. https://doi.org/10.1371/ journal.pone. 0165838

Sousa JC, Berto RF, Gois EA, Fontenele-Cardi NC, Honório-Júnior JERK, Richardson M, Rocha MFG, Camargo AACM, Pimenta DC, Cardi BA, Carvalho KM (2009) Leptoglycin: A new Glycine/Leucine-rich antimicrobial peptide isolated from the skin secretion of the South American frog Leptodactylus pentadactylus (Leptodactylidae). Toxicon 54: 23-32.

Souto WMS, Mourão JS, Barboza RRD, Alves RRN (2011) Parallels between zootherapeutic practices in Ethnoveterinary and Human Complementary Medicine in NE Brazil. Journal of Ethnopharmacology 134(3):753-767.

Souto WMS, Barboza RRD, Fernandes-Ferreira $\mathrm{H}$, Magalhães-Júnior AJC, Monteiro JM, Abichacra EA, Alves RRN (2018) Zootherapeutic uses of wildmeat and associated products in the semiarid region of Brazil: general aspects and challenges for conservation. Journal of Ethnobiology and Ethnomedicine 14(60):1-16.

Souza AVV, Santos US, Carvalho JRS, Barbosa BDR, Canuto KM, Rodrigues THS (2018) Chemical composition of essential oil of leaves from Lippia schaueriana Mart. collected in the caatinga area. Molecules 23:2480.

molecules23102480

Souza Lima M, Oliveira Bitencourt M, Furtado A, Torres-Rêgo M, Siqueira E, Oliveira R, Rocha $\mathrm{HO}$, Rocha KF, Silva-Júnior A, Zucolotto S, Fernandes-Pedrosa M (2017) Aspidosperma pyrifolium Has Anti-Inflammatory Properties: An Experimental Study in Mice with Peritonitis Induced by Tityus serrulatus Venom or Carrageenan. International Journal of Molecular Sciences 18:2248. https://doi.org/ 10.3390/ijms 18112248

Souza Lima MCJ, Soto-Blanco B (2010) Poisoning in goats by Aspidosperma pyrifolium Mart.: Biological and cytotoxic effects. Toxicon 55:320-324. https://doi.org/ 10.1016/j.toxicon.2009.08.004 
Souza Neto Júnior JC, Estevão LRM, Ferraz AA, Simões RS, Vieira MGF, Evêncio-Neto J (2019) Ointment of Ximenia americana promotes acceleration of wound healing in rats. Acta Cirúrgica Brasileira 34(3). https://doi.org/10.1590/ s0102-865020190030000007

Souza SMC, Aquino LCM, Jr ACM, Bandeira MAM, Nobre MEP, Viana GSB (2007) Antiinflammatory and antiulcer properties of tannins from Myracrodruon urundeuva Allemão (Anacardiaceae) in Rodents. Phytotherapy Research 21:220-225. https:// doi.org/10.1002/ptr.2011

Staines SS (2011) Herbal medicines: adverse effects and drug-herb interactions. Journal of the Malta College of Pharmacy Practice 17:3842.

Stashenko EE, Martínez JR, Cala MP, Durán DC, Caballero D (2013) Chromatographic and mass spectrometric characterization of essential oils and extracts from Lippia (Verbenaceae) aromatic plants. Journal of Separation Science 36:192-202. https://doi.org/ 10.1002/jssc.201200877

Tanaka M, Kendal JR, Laland KN (2009) From traditional medicine to witchcraft: why medical treatments are not always efficacious. PLoS One 4:e5192. https://doi.org/ 10.1371/journal.pone.0005192

Tiffany-Castiglioni E, Saneto RP, Proctor $\mathrm{PH}$, Perez-Polo JR (1982) Participation of active oxygen species in 6-hydroxydopamine toxicity to a human neuroblastoma cell line. Biochemical Pharmacology 31:181-188.

Trentin DS, Silva DB, Amaral MW, Zimmer KR, Silva MV, Lopes NP, Giordani RB, Macedo AJ (2013) Tannins Possessing Bacteriostatic Effect Impair Pseudomonas aeruginosa Adhesion and Biofilm Formation. PLoS One 8:e66257. https://doi.org/10.1371/journal.pone. 0066257

Tundis R, Xiao J, Loizzo MR (2017) Annona species (Annonaceae): a rich source of potential antitumor agents? Annals of the New York Academy of Sciences 1398:30-36. https:// doi.org/10.1111/nyas.13339

Van Vliet N, Moreno J, Gómez J, Zhou W, Fa JE, Golden C, Alves RRN, Nasi R (2017) Bushmeat and human health: Assessing the Evidence in tropical and sub-tropical forests. Ethnobiology and Conservation 6:1-45.
Vasconcelos SMM, Lima NM, Sales GTM, Cunha GMA, Aguiar LMV, Silveira ER, Rodrigues ACP, Macedo DS, Fonteles MMF, Sousa FCF, Viana GSB (2007) Anticonvulsant activity of hydroalcoholic extracts from Erythrina velutina and Erythrina mulungu. Journal of Ethnopharmacology 110:271-274. https://doi.org/10.1016/j.jep.2006.09.023

Vasconcelos SMM, Oliveira GR, Carvalho MM, Rodrigues ACP, Silveira ER, Fonteles MMF, Sousa FCF, Viana GSB (2003) Antinociceptive activities of the hydroalcoholic extracts from Erythrina velutina and Erythrina mulungu in mice. Biological and Pharmaceutical Bulletin 26:946-949.

Vera SS, Zambrano DF, Méndez-Sanchez SC, Rodríguez-Sanabria F, Stashenko EE, Luna JED (2014) Essential oils with insecticidal activity against larvae of Aedes aegypti (Diptera: Culicidae). Parasitology Research 113:26472654. https://doi.org/10.1007/s00436-014-39176

Viana GSB, Bandeira MAM, Matos FJA (2003) Analgesic and antiinflammatory effects of chalcones isolated from Myracrodruon urundeuva Allemão. Phytomedicine 10:189195. https://doi.org/ $10.1078 / 094471103321659924$

Vicuña GC, Stashenko EE, Fuentes JL (2010) Chemical composition of the Lippia origanoides essential oils and their antigenotoxicity against bleomycin-induced DNA damage. Fitoterapia 81:343-349. https:// doi.org/10.1016/j.fitote.2009.10.008

Vieira PB, Silva NLF, Silva GNS, Silva DB, Lopes NP, Gnoatto SCB, Silva MV, Macedo AJ, Bastida J, Tasca T (2016) Caatinga plants: natural and semi-synthetic compounds potentially active against Trichomonas vaginalis. Bioorganic and Medicinal Chemistry Letters 26:2229-2236. http://doi.org/10.1016/ j.bmcl.2016.03.061

Vieira PB, Silva NLF, Menezes CB, Da Silva MV, Silva DB, Lopes NP, Macedo AJ, Bastida J, Tasca T (2017) Trichomonicidal and parasite membrane damaging activity of bidesmosic saponins from Manilkara rufula. PLoS One 12. https://doi:10.1371/journal.pone.0188531 
Vigerelli H, Sciani JM, Jared C, Antoniazzi MM, Caporale GMM, Silva ACR, Pimenta DC (2014) Bufotenine is able to block rabies virus infection in BHK-21 cells. Journal of Venomous Animals and Toxins including Tropical Diseases 20(1):45. https://doi.org/10.1186/1678-9199-2045

Voss C, Eyol E, Berger MR (2006a) Identification of potent anticancer activity in Ximenia americana aqueous extracts used by African traditional medicine. Toxicology and Applied Pharmacology 211:177-187. https:// doi.org/10.1016/j.taap.2005.05.016

Voss C, Eyol E, Frank M, von der Lieth CW, Berger MR (2006b) Identification and characterization of riproximin, a new type II ribosome-inactivating protein with antineoplastic activity from Ximenia americana. FASEB Journal 20:1194-1196. https://doi.org/10.1096/fj.05-5231fje

World Health Organization (2017) World Malaria Report 2017. WHO, Geneva, Switzerland.

World Health Organization (2018) World Malaria Report 2018. WHO, Geneva, Switzerland.
Ximenes NC, Santos Júnior MA, Vasconcelos GS, Dias KCF, Jucá MM, Silva AH, Leal LKAM, Viana GSB, Sousa FCF, Vasconcelos SMM (2018) Ethanolic extract of Erythrina velutina Willd ameliorate schizophrenia-like behavior induced by ketamine in mice. Journal of Complementary and Integrative Medicine 16. https://doi.org/10.1515/jcim-2018-0038

Zhou Z, Jiang Z (2004) International trade status and crisis for snake species in China. Conservation Biology 18:1386-1394.

Zorofchian Moghadamtousi S, Karimian $\mathrm{H}$, Rouhollahi E, Paydar M, Fadaeinasab M, Abdul Kadir H (2014) Annona muricata leaves induce G1 cell cycle arrest and apoptosis through mitochondria-mediated pathway in human HCT-116 and HT-29 colon cancer cells. Journal of Ethnopharmacology 156:277289. https://doi.org/10.1016/j.je
Received: 20 August 2019

Accepted: 20 February 2020

Published: 19 March 2020 